
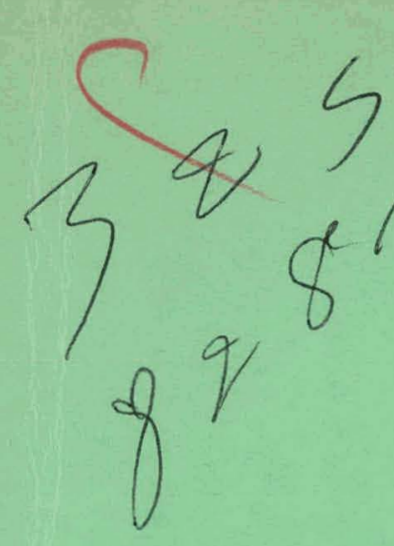

CHEMICAL PROCESSING TECHNOLOGY

QUARTERLY PROGRESS REPORT

January - March, 1962 


\section{DISCLAIMER}

This report was prepared as an account of work sponsored by an agency of the United States Government. Neither the United States Government nor any agency Thereof, nor any of their employees, makes any warranty, express or implied, or assumes any legal liability or responsibility for the accuracy, completeness, or usefulness of any information, apparatus, product, or process disclosed, or represents that its use would not infringe privately owned rights. Reference herein to any specific commercial product, process, or service by trade name, trademark, manufacturer, or otherwise does not necessarily constitute or imply its endorsement, recommendation, or favoring by the United States Government or any agency thereof. The views and opinions of authors expressed herein do not necessarily state or reflect those of the United States Government or any agency thereof. 


\section{DISCLAIMER}

Portions of this document may be illegible in electronic image products. Images are produced from the best available original document. 
PRICE \$1.00

\section{Available from the \\ Office of Technical Services \\ U. S. Department of Commerce \\ Washington 25, D. C.}

\section{LEGAL NOTICE}

This report was prepared as an account of Government sponsored work. Neither the United States, nor the Commission, nor any person acting on behalf of the Commission:

A. Makes any warranty or representation, express or implied, with respect to the accuracy, completeness, or usefulness of the information contained in this report, or that the use of any information, apparatus, method, or process disclosed in this report may not infringe privately owned rights; or

D. Assumes any liabilities with respect to the use of, or for damages resulting from the use of any information, apparatus, method, or process disclosed in this report.

As used in the above, "person acting on behalf of the Commission" includes any employee or contractor of the Commission, or employee of such contractor, to the extent that such employee or contractor of the Commission, or employee of such contractor prepares, disseminates, or provides access to, any information pursuant to his employment or contract with the Commission, or his employment with such contractor. 


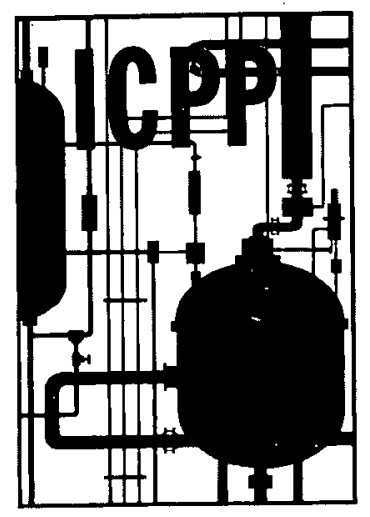

IDO- 14589

AEC Research \& Development Report General, Miscellaneous, and Progress Reports

TID-4500 (17th Ed.)

Issued: June 29, 1962

\title{
CHEMICAL PROCESSING TECHNOLOGY
}

QUARTERLY PROGRESS REPORT

January - March, 1962

\author{
J. R. Huffman \\ Assistant Manager, Technical \\ J. A. McBride \\ Manager, Chemical Technology \\ J. R: Bower * \\ Editor
}

\section{PHILLIPS \\ PETROLEUM \\ COMPANY}

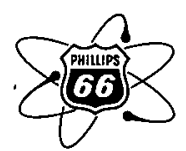

Atomic Energy Division

Contract AI (10-1)-205

Idaho Operations Office

U. S. ATOMIC ENERGY COMMISSION 
Previous Quarterly Reports in the ICPP Series

\begin{tabular}{c} 
Quarter \\
\hline 2 \\
3 \\
4
\end{tabular}

1954

Number

IDO-14324

IDO- 14337

IDO- 14350

1955

Quarter

1

2

3

4

Number

IDO- 14354

IDO- 14362

IDO- 14364

IDO- 14383

1956

Quarter

1

2

3

4

1957

Quarter

1
2
3
4

Number

IDO- 14410

IDO- 14419

IDO- 14422

IDO- 14430

1958

Quarter

1
2
3
4

Number

IDO- 14443

IDO- 14453

IDO-14457

IDO- 14467

1959

Quarter

1

2

3

4

Number

IDO- 14471

IDO- 14494

IDO- 14509

IDO- 14512

1960

Quarter

Number

1

2

3

4

IDO- 14520

IDO- 14534

IDO- 14540

IDO- 14553

1961

Quarter

1
2
3
4

Number

IDO- 14560

IDO- 14567

IDO- 14574

IDO- 14583 


\section{CHEMICAL PROCESSING TECHNOLOGY QUARTERLY PROGRESS REPORT JANUARY - MARCH, 1962}

\section{SUMMARY}

The ICPP processed aluminum fuel, principally of the MTR-ETR type, during this quarter, completing the run started during the previous quarter. Processing rate averaged 90 per cent of flow sheet valuesfor the entire operating period, and a uranium recovery of 99.85 per cent was achieved.

Aqueous zirconium fuel processing studies have continued with the objective of adapting the hydrofluoric acid process to continuous dissolution-complexing in order to increase the capacity of the ICPP process while using as much existing equipment as possible to minimize costs. Good results were indicated in a 190-hour run dissolving 2 per cent uranium-zirconium fuel in a Monel dissolver using $4.8 \mathrm{M} \mathrm{HF}-0.03 \mathrm{M} \mathrm{HNO}_{3}$ dissolvent at $200^{\circ} \mathrm{F}$; insoluble material did not accumulate in the dissolver, although a uranium-containing film was formed, apparently in small, equilibrium quantity. Shorter term continuous laboratory dissolutions indicated that $4.8 \mathrm{M}$ acid was preferable to $10 \mathrm{M}$ acid for the acid feed rate/fuel surface ratios proposed, resulting in dissolver products of greater stability and higher uranium content. Additional laboratory data are presented on uranium tetrafluoride hydrate form and solubility, together with maximum dissolvable uranium compositions with Zircaloy under various flowsheet conditions.

Processing of aluminum alloys containing high silicon was found to present no unusual problems in laboratory studies. Siliceous residues resulting from dissolution of aluminum-uranium alloys containing 2 per cent silicon in nitric acid contained no insoluble uranium, and the occluded uranium was readily removed by solvent extraction with TBP-Amsco, the normal process extractant.

Studies of the electrolytic dissolution process were directed at corrosion measurement and prevention, development of analytical systems for process control, and testing of structural insulating materials for use in the process environment. A simple measurement of corrosion potential is shown to indicate the instantaneous corrosion rate of stainless steel process equipment containing electrolytic dissolver solutions; this measurement could determine the amount of cathodic protection that might be used to protect certain corrosion sensitive areas. An in-line process solution analyzer has been developed and a prototype constructed and placed in use; by simultaneous measurement of electrical conductance of two flowing stream samples (one, the original concentration, and the other, a fixed dilation), the concentrations of both dissolver acid and dissolved stainless steel components are determined.

The Demonstrational Waste Calcination Facility was operated continuously for 250 hours, showing good mechanical operability of process equipment and close control of process conditions. Escape of solids past the calciner cyclone into the liquid scrubbing system has continued to be the principal area of concern. Pilot plant calciner studies indicated the rate of solids carry-over from the cyclone was nearly constant, whether the bed was predominantly 
alpha or amorphous alumina; solids elutriation rate from the bed did vary with alumina crystal form. In laboratory studies directed toward calcination of wastes from stainless steel processing, the nitrates of iron, nickel, and chromium. were found to decompose thermally at temperatures approximately the same as those used for aluminum nitrate calcination.

Miscellaneous basic process studies reported include experimental verification of analog results on air pulsed extraction column operating characteristics, indication of a method of sampling individual aqueous or organic phases in an operating column, and further evidence of the effectiveness of the cascade control system on the thermosiphon product evaporator. Progress is reported on design of neutron poison plate structures for protection of vessels of unsafe geometrical configuration from criticality incidents in the presence of high concentrations of enriched uranium. 


\section{CHEMICAL PROCESSING TECHNOLOGY QUARTERLY PROGRESS REPORT \\ JANUARY - MARCH, 1962}

\section{CONTENTS}

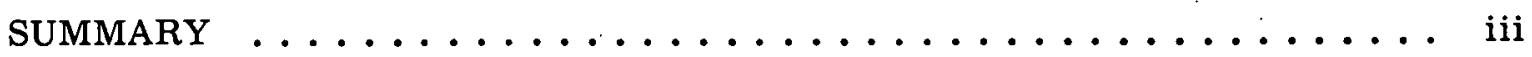

I. ICPP OPERATIONAL SCHEDULE, PERFORMANCE, AND PROBLEMS . 1

1. ICPP PROCESSING SCHEDULE $\ldots \ldots \ldots \ldots \ldots \ldots \ldots$

2. ICPP OPERATIONAL PERFORMANCE ............... 1

3. PLANT ASSISTANCE PROBLEMS ................. 1

3.1 Tritium in ICPP Process Streams ............... . . 1

3.2 Corrosion of Type 316 ELC Stainless Steel

in Fluoride-Bearing Zirconium Process Wastes ......... 2

4. SIMULTANEOUS PROCESSING OF ZIRCONIUM

AND ALUMINUM FUELS .................... 3

II. AQUEOUS PROCESS STUDIES . . . . . . . . . . . . . . . . 5

1. AQUEOUS ZIRCONIUM FUEL PROCESSING ............ 5

1.1 Solubility of Uranium Tetrafluoride .............. 5

1.2 Continuous Dissolution of Zirconium Alloy

Fuel with Hydrofluoric Acid Laboratory Scale . . . . . . . . . 7

1.3 Continuous Zirconium Fuel Dissolution in the Pilot Plant . . . . 12

2. AQUEOUS ALUMINUM FUEL REPROCESSING . . . . . . . . . . 13

2.1 Effect of High Silicon Content

in Reprocessing of Aluminum Alloys ................ 13

III. ELECTROLYTIC DISSOLUTION SYSTEMS $\ldots \ldots \ldots \ldots$

1. CORROSION RATE OF STAINLESS STEEL

IN ELECTROLYTIC DISSOLVER SOLUTIONS . . . . . . . . . . . 15

2. ELECTROCHEMISTRY OF TYPE 304

STAINLESS STEEL IN NITRATE SOLUTIONS $\ldots \ldots \ldots \ldots$

3. ELECTROLYTIC DISSOLVER PRODUCT ANALYZER . . . . . . . 18

4. NON-METALLIC MATERIALS OF

CONSTRUCTION IN ELECTROLYTIC SYSTEMS $\ldots \ldots \ldots \ldots$

IV. NEW WASTE TREATMENT METhODS . . . . . . . . . . . . 21

1. DISPOSAL OF LOW-LEVEL RADIOACTIVE WASTES . . . . . . 21 
1.1 Adsorption of Strontium and Cesium ............. 21

1.2 Adsorption of Tritium $\ldots \ldots \ldots \ldots \ldots . \ldots \ldots \ldots$

V. WASTE CALCINATION DEVELOPMENT AND DEMONSTRATION $\ldots \quad 22$

1. OPERATION OF THE DEMONSTRATIONAL

WASTE CALCINING FACILITY (DWCF) ........... 23

1.1 Analysis and Correction of NaK Tube Vibration ........ 23

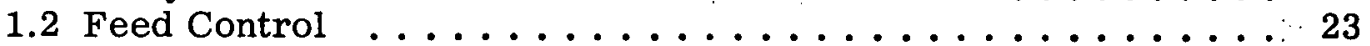

1.3 Solids Carry-over ...................... 23

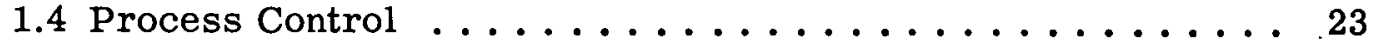

2. PILOT PLANT DEVELOPMENT . . . . . . . . . . . . . . 24

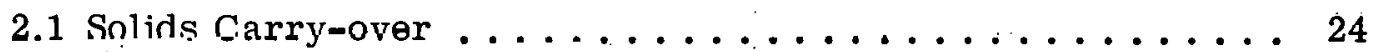

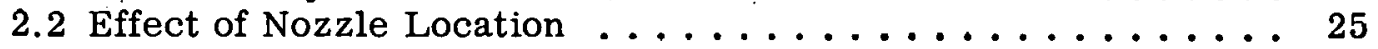

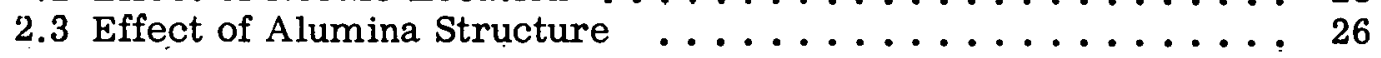

3. LABORATORY STUDIES OF STAINLESS STEEL CALCINATION . . 26

4. POT CALCINATION $\ldots \ldots \ldots \ldots \ldots \ldots \ldots \ldots \ldots \ldots \ldots$

VI. BASIC PROCESS STUDIES AND EQUIPMENT DEVELOPMENT . . . . 28

1. EXPERIMENTAL AIR PULSER ................. 28

2. PULSE COLUMN DYNAMICS .................... 28

3. EVAPORATOR CONTROL .................... 29

4. CALCULATIONAL TECHNIQTIFS FOR DETERMINING ETFECTS OF NUCLEAR POISON . . . . . . 29

4.1 Development of Calculational Methods . . . . . . . . . . . 29

4.2 Modification of Methods for Non-uniform Plate Spacing . . . . 30

VII. REPORTS AND PUBLICATIONS ISSUED DURING THE QUARTER . 32

VIII REFERENCES ......................... 33

\section{FIGURES}

1. Solubility of uranium tetrafluoride in zirconium-hydrofluoric acid solutions as a function of fluoride concentration

and fluoride-to-zirconium mole ratio $\ldots \ldots \ldots \ldots \ldots$

2. Continuous laboratory dissolver $\ldots \ldots \ldots \ldots \ldots \ldots$

3. Influence of temperature and direction of acid

flow on dissolution of uranium in Zircaloy-2-uranium fuel $\ldots \ldots \ldots 11$ 
4. Effect of temperature of dissolution

on uranium residue left in dissolver . . . . . . . . . . . . . . . 11

5. Potential-current density (corrosion rate) relationships for type 304 stainless steel at 25 and $85^{\circ} \mathrm{C}$ in a dissolver solution containing $5 \mathrm{M} \mathrm{HNO}_{3} \quad \ldots \ldots \ldots \ldots \ldots \ldots \ldots \ldots$

6. Corrosion rates as functions of potential and temperature for type 304 stainless steel in a dissolver solution containing $5 \underline{\mathrm{M}} \mathrm{HNO}_{3} \ldots \ldots 17$

7. Inline conductance analyzer ....................... 19

8. Pulse amplitudes in experimental air pulser .............. 28

\section{TABLES}

I. Composition of $\mathrm{Z}$ irconium Process Raffinate $\ldots \ldots \ldots \ldots \ldots$

II. Conditions and Results for Continuous Laboratory Dissolution of $\mathrm{Z}$ irconium Fuel .................. 10

III. Changes in Plastics Samples after Boiling in Nitric Acid . . . . . . 20

IV. Visible Changes in Plastics Samples after Gamnia Irradiation _ . . . 20

V. Solids Carry-over in the Two-foot-square Calciner . . . . . . . . 25

VI. Thermal Decomposition of Stainless Steel and Aluminum Nitrates .. 26

VII. Comparison of Calculational Methods for Uniform Plate Spacing . . . . 29 


\section{THIS PAGE \\ WAS INTENTIONALLY \\ LEFT BLANK}




\title{
I. ICPP OPERATIONAL SCHEDULE, PERFORMANCE, AND PROBLEMS
}

\author{
1. ICPP PROCESSING SCHEDULE \\ (R. S. P'Pool)
}

ICPP run 19 was completed in March; decontamination of cells $G$ and $\mathrm{H}$ is now in progress. Fuels processed during this run were primarily MTR-ETR elements, plus small quantities of Chalk River and other aluminum-uranium elements. Overall uranium recovery for the run was 99.85 per cent, including uranium from recycle and RaLa solutions.

Dissolution rates averaged 90 per cent of flowsheet, based on uranium dissolved, for the entire period of operation; dissolver charging rates, based on total metal, averaged somewhat less because of the high uranium content of some ETR elements. The first extraction cycle operated at about 87 per cent of flowsheet rates, including cleanout and recycle operations. Second and third extraction cycle operations were smooth and trouble-free, at essentially full flowsheet rates. No significant changes in the present CPM flowsheet were indicated as a result of this run.

Four barium-140 (RaLa) runs were made during this quarter, producing a total of 99,000 curies. Individual batches varied from 21,300 to 28,100 curies; yields ranged from 40 to 54 per cent of theoretical.

\section{ICPP OPERATIONAL PERFORMANCE \\ (R. S. P'Pool)}

The new equipment installed in the first cycle extraction system continued the satisfactory operation described previously [1]. The extraction column air pulsers were trouble-free throughout the run, although pulse energy input to the $1 \mathrm{~A}$ column was restricted because of feed control and column instability problems. The new $\mathrm{H}-130$ product evaporator and its cascade control system gave excellent product quality control at an average boilup rate of about 200 liters per hour.

The 1A. column interface control problems, attributed to high surfactant content of the feed stream, were controlled during the run by maintaining a gelatin concentration of 0.05 grams per liter in the feed. Redesign of the 1A column feed and interface control systems has been initiated.

\section{PLANT ASSISTANCE PROBLEMS}

\subsection{Tritium in ICPP Process Streams (R. S. P'Pool, H. E. Stelling)}

Two ICPP process strearrs were analyzed for tritium during run 19 to determine the amounts of tritium being discharged to ground water and to 
waste storage. The samples were taken during dissolution and first cycle extraction of ETR fuel elements. The analytical results are tabulated below:

\section{Sample}

Process waste evaporator condensate (PEW)

First cycle raffinate (Batch 104) (IARm)

First cycle raffinate (Batch 112) (IARm)
$\underline{\mathrm{H}^{3}(\mu \mathrm{c} / \mathrm{ml} \text { solution })}$

1.28

Based on these data, and assuming current flow sheet conditions, it is estimated that each ETR fuel element contributed approximately 0.3 curie of tritium to the IAR stream (permanent storage) and 0.1 curie to the PEW condensate stream which is discharged to the ground via the service waste well.

\subsection{Corrosion of Type 316 ELC Stainless Steel in Fluoride-Bearing Zirconium} Process Wastes (T. L. Hoffman)

Aqueous raffinate waste from the zirconium fuel recovery process is stored in underground type 316 ELC stainless steel vessels. This waste contains mixtures of fluozirconic acids, nitric acid, and aluminum nitrate, with small amounts of chromium and tin. Corrosion evaluation of test specimens hasibeen undertaken to predict the life of the existing .waste storage vessels, and to provide data for the design of future storage facilities. Observations.on plant test samples after five years exposure indicate that the usable life of the present 316. ELC stainless steel tanks will exceed 40 years, and it is recommended that 316 ELC stainless steel be considered as a material of construction for future tanks in similar service.

3.21. Sample Preparation: Evaluations were conducted on four corrosion specimens which were withdrawn after. 1876 days immersion in a storage vessel containlng radioactive process wastes from the hydrofluoric "acid:zirconium fuel processing operation.

Two of the specimens were representative of the 9/16-inch-thick 316 ELC stainless steel plate and weld deposit used to erect the zirconium process waste storage vessel. The inert gas automatic metallic-arc welding technique was used. These specimens were cut from tabs which the fabricator prepared at the vessel's erecting site. A chemical analysis of one of the weld deposits indicated 0.062 per cent carbon.

Two specimens had been prepared locally for this study. Stainless steel 316 ELC wrought material was turned into open-seam tubes from 0.125 -inchthick plates. The tubes were formed around mandrels having diameters either 10 or 20 times the sheet thickness, leaving a 1/8-inch opening, which was closed by compression and heliarc-welded with 316 ELC uncoated wire. Oneinch-wide bands were cut from the tubes and all edges were machined to $1 / 32$-inch radius.

One specimen, selected from a tube whose diameter was 20 times the material thickness, had been sensitized by a one-hour heat treatment at $1250^{\circ} \mathrm{F}$ followed by a water quench. The second, from a tube whose diameter was 10 times the material thickness, was tested in the as-welded condition. 
3.22 Process Solution. The corrodent during these studies was the actual zirconium process radioactive waste in a cooled 30,000-gallon 316 ELC storage vessel. This waste raffinate is maintained at $25^{\circ} \mathrm{C}$ by the cooling coils. The composition of the waste (Table I) is presented on the basis of flow sheet design estimates as well as the calculated composite of analytical results on individual batches of process waste streams.

\section{TABLE I}

COMPOSITION OF ZIRCONIUM PROCESS RAFFINATE

\begin{tabular}{|c|c|c|}
\hline Element & $\begin{array}{c}\text { Process Design } \\
\text { Flow Sheet }\end{array}$ & $\begin{array}{c}\text { Average Process } \\
\text { Raffinate }\end{array}$ \\
\hline Zirconium ( $\underline{M})$ & 0.5249 & 0.4825 \\
\hline Fluoride ( $\underline{M})$ & 2.863 & 2.895 \\
\hline Aluminum ( & 0.7158 & 0.660 \\
\hline $\operatorname{Tin}(\underline{M})$ & 0.007 & 一 \\
\hline Total acid (M) & 0.71 & 1.070 \\
\hline Nitrate $(\underline{M})$ & 2.101 & 1.980 \\
\hline Chromate (M) & 0.0095 & 0.005 \\
\hline Tributyl phosphate $(\mathrm{g} / \mathrm{l})$ & 0.10 & 0.10 \\
\hline Specific gravity & 1.183 & 1.195 \\
\hline
\end{tabular}

3.23 Test Results. Corrosion penetration based on weight loss was less than 0.01 mil per month for any of the four specimens immersed in the ICPP high-activity zirconium process waste solution for 5.1 years at $25^{\circ} \mathrm{C}$. Individual rates actually ranged from 0.005 to 0.007 mil per month. From microexamination, 66 per cent of the original machine marks existed on the exposed specimens. Very mild interdendritic attack was present on the weld areas of all specimens. Pitting was absent on all specimens.

\section{SIMULTANEOUS PROCESSING OF ZIRCONIUM AND ALUMINUM FUELS (J. I. Stevens, J. R. Bower)}

The possibility of simultaneous processing of zircunium and aluminum fuels at the ICPP has been considered a number of times because of the potential savings in waste storage costs through utilization of the aluminum dissolver solution as the complexing agent for the zirconium solution. In the absence of such blending, it is necessary to add fresh aluminum nitrate to complex the zirconium dissolver solution, thus contributing cold chemical bulk to be stored with the radioactive wastes. Recently, the interest has been increased by data which. indicate that the corrosion properties of certain 
compositions of blended zirconium and aluminum raffinates would permit their storage in the presently available ICPP stainless steel tanks provided for aluminum processing wastes [1, 2, 3]. Further, in a recent report from ORNL [4] it was suggested that an equal volume mixture of dissolver solutions from MTR fuel and $\mathrm{Zr}-\mathrm{U}$ alloy fuels could be prepared as feed for the extraction system.

The theoretical feasibility of blending zirconium and uranium dissolver solutions to obtain a complexed fuel suitable for extraction is unquestioned, although control problems would undoubtedly arise with the precise ratio blending and adjustments required to keep the composite of the two variable dissolver effluents within the narrow stability region of the zirconium-aluminumfluorine-nitrate system. Increased uranium recovery capacity also would be possible by use of blended streams in conjunction with properly matched dissolution equipment for the two fuel types.

The ICPP has not proceeded in the direction of simultaneous processing of these two fuel types, however, since total uranium recovery capacity has nül been a prublem, and considerably higher operating costs and investment would be involved. Simultaneous operation of the two dissolver systems, which would be required to provide a composite feed for the extraction system, would demand an expansion of the present operating staff, resulting in a significant increase in operating cost; additional investment would be required either to match the dissolution capacities of the two systems or to provide surge capacity and blending control.

Any early expansion of the zirconium processing facilities, which may be dictated by need for increased capacity for this type of fuel, will be by the continuous flow sheet, discussed in the following section. This revised process results in a substantial reduction in the amount of complexer solution necessary per unit of zirconium processed, lessening the incentive to attempt a blending operation. The recision whether to blend foodo at the time of installation of a new zirconium dissolver will have to be based on a balance vetween possible savings in waste raffinate storage vs increased operating costs and the complexity of instrumentation and process equipment necessary to achieve satisfactory blending of the two variable dissolver streams into the limited stability range possible in the zirconium-aluminum-fluorinenitrate system. 


\section{Il. AQUEOUS PROCESS STUDIES}

(Section Chiefs: K. L. Rohde, Chemistry; J. I. Stevens, Development Engineering)

\section{AQUEOUS ZIRCONIUM FUEL PROCESSING}

The existing process at the ICPP for the processing of uranium-zirconium alloy fuel utilitizes the batch dissolution of the fuel in hydrofluoric acid, batch complexing of fluoride by aluminum nitrate, and solvent extraction by tributylphosphate. A modified process of higher capacity is under development in which the fuel is dissolved continuously in hydrofluoric acid. In the laboratory, chemical studies are directed to the kinetics of fuel dissolution, the solubility of uranium tetrafluoride in dissolver solution, and corrosion behavior of materials of construction. Extended dissolution runs are being made in the pilot plant in a one-half-inch diameter continuous dissolver.

The laboratory experiments are designed to investigate the limiting conditions under which the process can be operated, while the pilot plant dissolver was operated continuously under average flow sheet conditions, primarily to check out long term corrosion and solution stability in a flow sheet suitable for use in process design. Consequently, the results reported are not directly comparable between laboratory and pilotplant, although the satisfactory runs in the pilot plant verify the chemical studies. A continuous dissolver using upflow of dissolvent and $0.03 \mathrm{M} \mathrm{HNO}_{3}$ as oxidant is acceptable for dissolving two weight per cent uranium-zirconium fuel.

\subsection{Solubility of Uranium Tetrafluoride (D. W. Rhodes, Problem Leader; B. E. Paige)}

A knowledge of the solubility of uranium tetrafluoride is important in developing a process for the continuous dissolution of two to three per cent uranium-Zircaloy fuel in hydrofluoric acid. The limiting capacity factor in a homogeneous system, without oxidant for uranium, is the solubility of uranium tetrafluoride in dissolver product solutions. Experience with such hydrofluoric acid flow sheets is limited to fuels containing only slightly greater than one per cent uranium. The effect of temperature on the solubility of uranium tetrafluoride was studied because an increase in uranium solubility with increasing temperature would permit the dissolving of fuels containing a greater percentage of uranium. The solid species formed from saturated solutions of $5 \mathrm{M}$ hydrofluoric acid were also studied because of the possibility that a "slurry" flow sheet containing uranium tetrafluoride solids might be feasible.

1.11 Hydrates of Uranium Tetrafluoride. Laboratory experiments were first conducted to determine the types of uranium tetrafluoride hydrates formed in prooess solutions containing $5 \mathrm{M}$ and $10 \mathrm{M}$ fluoride. Uranium wire was dissolved in hydrofluoric acid at several different temperatures until saturation was achieved. The X-ray diffraction patterns of the solids that precipitated indicated that $\mathrm{UF}_{4} \cdot 3 / 4 \quad \mathrm{H}_{2} \mathrm{O}$ formed at $95^{\circ} \mathrm{C}$ in either $5 \mathrm{M}$ or $10 \mathrm{M}$ hydrofluoric acid, and also at $60^{\circ} \mathrm{C}$ in $10 \mathrm{M}$ hydrofluoric acid. At $60^{\circ} \mathrm{C}$ in $5 \overline{\mathrm{M}}$ hydrofluoric acid, $\mathrm{UF}_{4} \cdot 2-1 / 2 \quad \mathrm{H}_{2} \mathrm{O}$ was the major solid component with some of the lower hydrate still present. At $35^{\circ} \mathrm{C}$ only the $\mathrm{UF}_{4} \cdot 2-1 / 2 \mathrm{H}_{2} \mathrm{O}$ was formed in both $5 \mathrm{M}$ and $10 \mathrm{M}$ hydrofluoric acid. To date, the material produced in small bench scale continuous dissolvers using $10 \mathrm{M}$ hydrofluoric acid dissolvent has been identified 
as the lower hydrate form $\left(\mathrm{UF}_{4} \cdot 3 / 4 \mathrm{H}_{2} \mathrm{O}\right)$, presumably because the operating temperature was about $90^{\circ} \mathrm{C}$. However, using a dilute flow sheet with $5 \mathrm{M}$ fluoride, $\mathrm{UF}_{4} \cdot 2-1 / 2 \mathrm{H}_{2} \mathrm{O}$ probably can be produced by maintaining the temperature at $60^{\circ} \mathrm{C}$ or lower.

Literature review ${ }^{[5]}$ indicates that $\mathrm{UF}_{4} \cdot 3 / 4 \mathrm{H}_{2} \mathrm{O}$ is a dense, fine precipitate with tap density of 2.7 grams per cubic centimeter; the $\mathrm{UF}_{4} \cdot 2-1 / 2 \mathrm{H}_{2} \mathrm{O}$ is described as a voluminous, easily-filtered precipitate with a tap density of 0.5 grams per cubic centimeter. The $\mathrm{UF}_{4} \cdot 2-1 / 2 \mathrm{H}_{2} \mathrm{O}$, which is produced at the lower temperature, is more readily oxidized to uranium (VI) than the lower hydrate; inasmuch as it also has a lower density, it may be the preferable form if other physical properties are satisfactory. Operation of a continuous dissolver will be necessary to determine whether one of these hydrates has less tendency to collect in the dissolver than the other hydrate.

1.12 Solubility of Uranium Tetrafluoride. The solubility of uranium tetrafluoride was determined in batch experiments using solid anhydrous uranium tetrafluoride and synthetic dissolver product solution prepared by dissolving Zircaloy-2 in 10M hydrofluoric acid without oxidant, and filtering off the tin solids. The solution and solid were placed in a polyethylene bottle, purged with nitrogen, and capped tightly to prevent oxidation of the uranium. The solutions were heated for 24 hours at $95^{\circ} \mathrm{C}$, then maintained at the desired temperature for another 24 hours. Aliquots of the supernatant liquid were diluted with uranium-free dissolver product solution for analysis. Analyses were made using both the standard colorimetric method for total uranium and direct spectrophotometric measurement of the uranium(IV). with standards prepared from dissolver product solution. The results of these two methods were in close agreement, indicating that essentially no oxidation of the uranium had occurred.

Solubility data were obtained in solutions containing a fluoride-to-zirconium mole ratio of 5.0 at $23,40,60$, and $95^{\circ} \mathrm{C}$, for a $10 \mathrm{M}$ fluoride solution, and at 23,60 , and $95^{\circ} \mathrm{C}$ for $3 \mathrm{M}, 5 \mathrm{M}$ and $8 \mathrm{M}$ fluoride solutions. No significant difference in solubility was found over this temperature range for a given solution composition. Phase transformations between $\mathrm{UF}_{4}, \mathrm{UF}_{4} \cdot 3 / 4 \mathrm{H}_{2} \mathrm{O}$, and $\mathrm{UF}_{4} \cdot 2-1 / 2$ $\mathrm{H}_{2} \mathrm{O}$ are very slow, depending upon the temperature. Thus, while the constant solubility between 23 and $95^{\circ} \mathrm{C}$ probably does not represent equilibrium conditions, the data are significant in interpreting dissolver behavinr. The average solubility values for each solution over this temperature range are given in Figure 1, together with similar data at $25^{\circ} \mathrm{C}$ previously reported by Argonne National Laboratory [6]. Several values obtained from laboratory continuous dissolver runs also are plotted in Figure 1 and are in general agreement with the other solubility data. The results show that the solubility of uranium tetrafluoride increases with either decreasing fluoride-to-zirconium mole ratio or with increasing total fluoride and zirconium concentrations. However, solutions containing $10 \mathrm{M}$ fluoride and low fluoride-to-zirconium mole ratios are unstable with respect to zirconium precipitation so that the most practicable flow sheets require low fluoride-to-zirconium mole ratios and low fluoride concentrations for stability. This is the basis for choosing a "dilute flow sheet" using approximately $5 \underline{\mathrm{M}}$ hydrofluoric acid. 


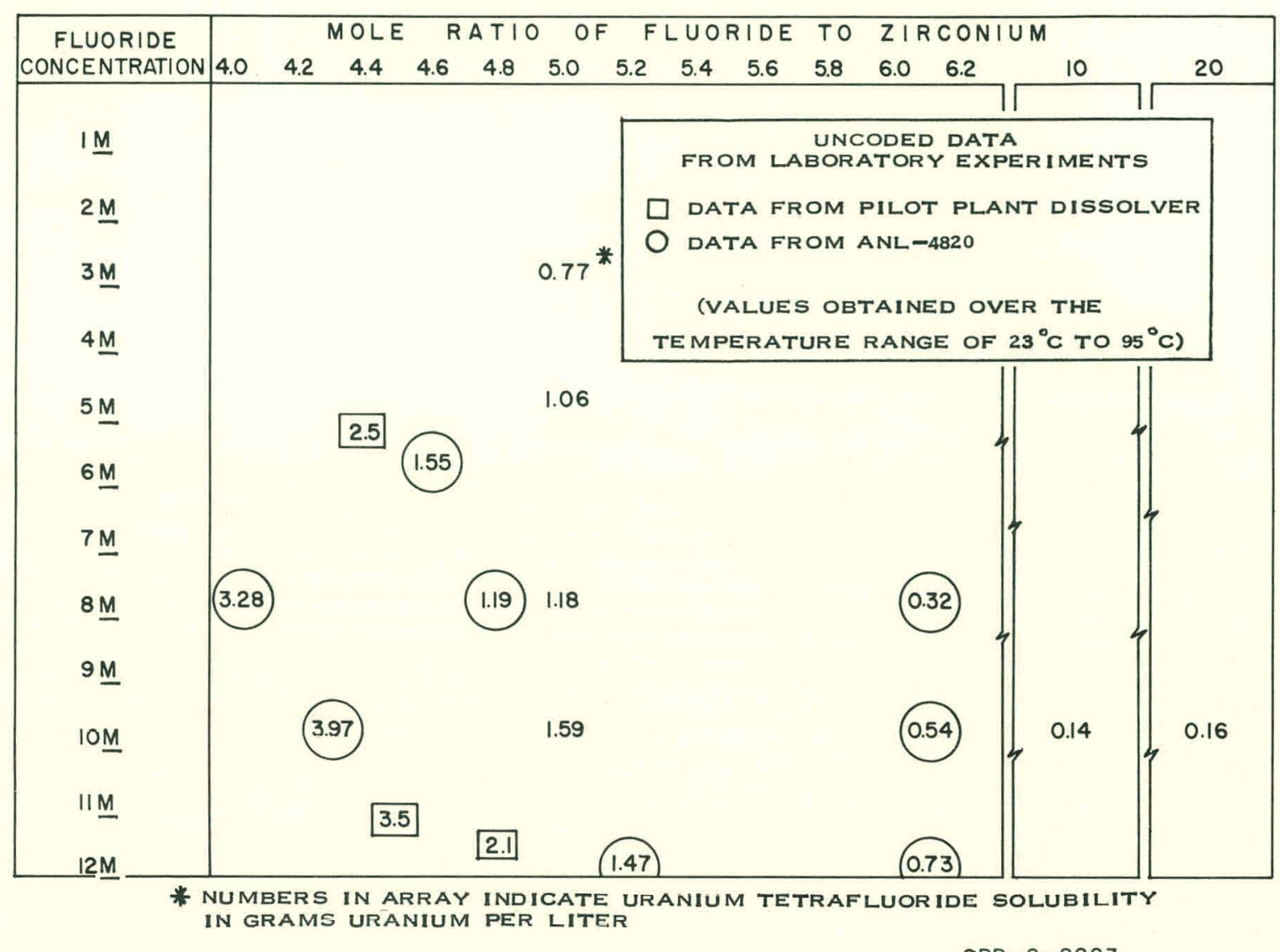

Fig. 1 Solubility of uranium tetrafluoride in zirconium-hydrofluoric acid solutions as a function of fluoride concentration and fluoride-to-zirconium mole ratio.

1.2 Continuous Dissolution of Zirconium Alloy Fuel with Hydrofluoric Acid Laboratory Scale (D. W. Rhodes, Problem Leader; B. J. Newby, L. A. Decker)

A one-inch-diameter laboratory dissolver was constructed of Monel to test a number of adaptations of batch-type flow sheets [7] for the continuous dissolution of zirconium-uranium alloy fuels containing more than two per cent uranium.

Two to three per cent uranium-Zircaloy-2 fuel was dissolved continuously, without the aid of oxidant, in $4.8 \mathrm{M}$ hydrofluoric acid at a dissolvent feed-rateto-fuel-surface ratio as low as $0.04 \mathrm{~cm} / \mathrm{min}$ to produce a stable dissolver product. Uranium losses to the dissolver and the quantity of uranium dissolved from the uranium-zirconium alloy were very largely dependent upon the operating temperature of the dissolver. The stability and composition of dissolver products were somewhat dependent on the dissolvent feed-rateto-fuel-surface ratio; this dependency was more noticeable when $10 \mathrm{M}$ hydrofluoric acid was used as the dissolvent than when $4.8 \mathrm{M}$ hydrofluoric acid was used.

1.21 Methods and Equipment. A photograph of the one-inch-diameter laboratory Monel dissolver and auxiliary equipment is shown in Figure 2. Feed solution is pumped into the bottom of the dissolver; product overflows 


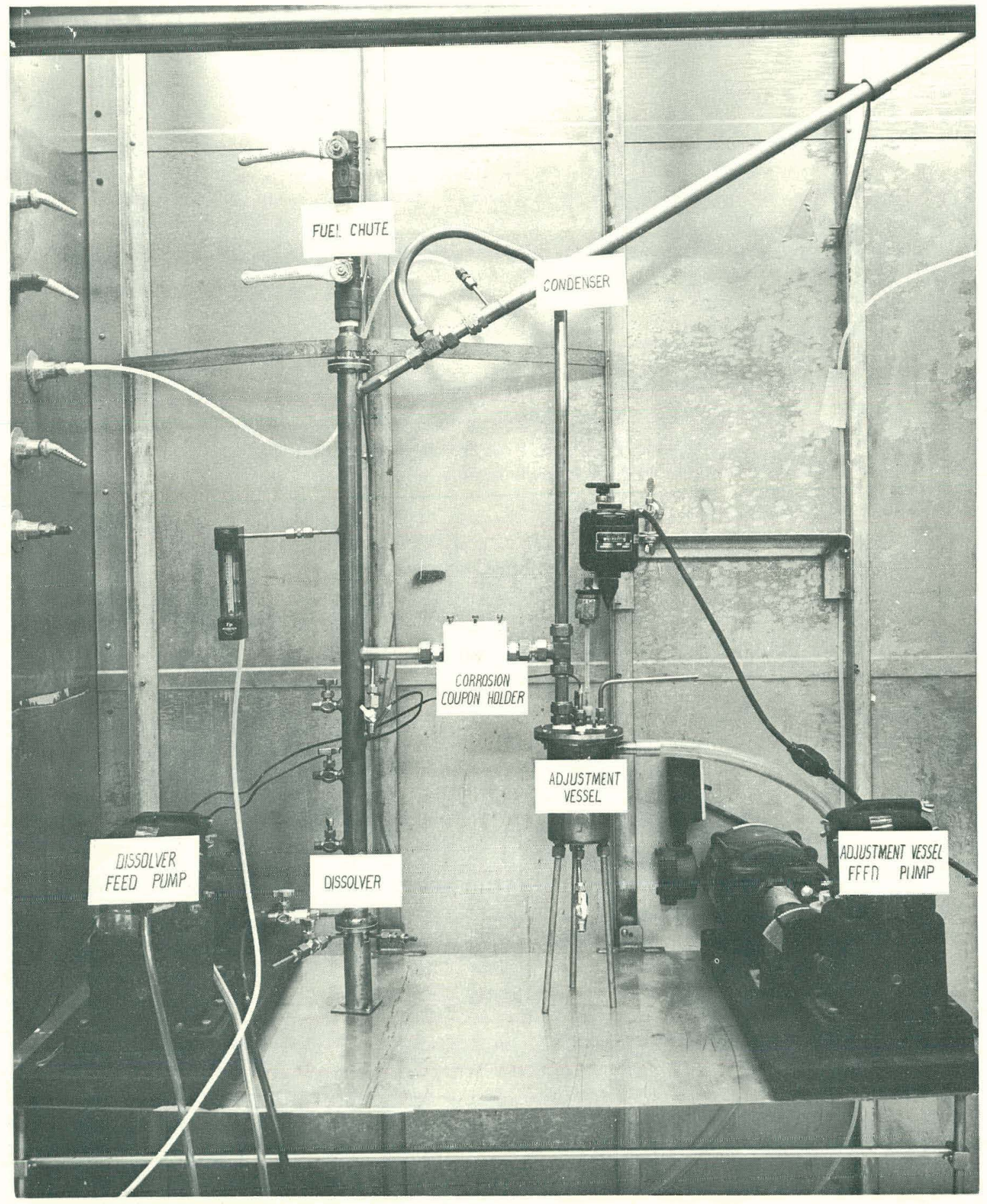

Fig. 2 Continuous laboratory dissolver.

from the dissolver, through a Teflon corrosion coupon holder, and into a Monel adjustment vessel. The dissolver contains several sampling ports. Adjustment solution enters the adjustment vessel through a tube in the top and leaves through an overflow tube. Solution within the vessel can be stirred and sampled. Nitrogen gas is fed into the dissolver during dissolution through 
a line above the dissolver cutlet. Temperatures within the dissolver and adjustment vessel are measured with internal thermocouples. Elevated temperatures are obtained with heating tape wrapped around the dissolution section. Lower temperatures are maintained by inserting the dissolution section into a constant temperature water bath.

The dissolver shown in Figure 2 was modified by appropriate means for downflow and recirculating dissolution. During downflow operation, feed was pumped into the dissolver through the nitrogen inlet, nitrogen was metered into the dissolver through one of the sampling ports, and dissolver product left the dissolver through a line in the bottom, thence up through the corrosion coupon holder. In recirculating operation, dissolver product was removed from the dissolver at a rate of 300 milliliters per minute by a positive displacement pump through a line one inch below the dissolver outlet and was pumped back into the bottom of the dissolver. Hydrofluoric acid feed was pumped into the dissolver through the recirculating line.

Runs were started with the dissolver filled to the outlet with dissolver solutions (prepared by batch dissolution or from a previous continuous dissolution) having a zirconium concentration equal to that desired for the dissolver product. Rate of fuel addition was regulated to maintain within the dissolver, undissolved fuel having a surface area of approximately 320 square centimeters at all times; ie, a depth of six inches of fuel. At the beginning of a run this amount of fuel was added prior to hydrofluoric addition. Zircaloy-2 or two to three per cent uranium-Zircaloy-2 alloy was used as fuel. The length of a dissolution run depended upon how quickly dissolution equilibrium was attained. It was assumed that the dissolver was at equilibrium when three consecutive specific gravity measurements of dissolver product, taken at half-hour intervals, had the same approximate value. In general, equilibrium was reached within three hours and the total run time was about six hours. Uranium adhering to dissolver walls was removed by boiling with 20 per cent sodium hydroxide in the presence of metallic zinc, for purposes of material balance determination.

1.22 Influence of Dissolvent Feed-Rate-to-Fuel-Surface Ratio and Hydrofluoric Acid Concentration. The dissolvent feed-rate-to-fuel-surface ratio was varied from 0.5 to 0.02 centimeter per minute in runs using $10 \mathrm{M}$ hydrofluoric acid as the dissolvent; in runs using $4.8 \mathrm{M}$ hydrofluoric acid the ratio was varied from 0.4 to 0.04 centimeter per minute. Increasing the dissolvent feed-rateto-fuel-surface ratio in dissolutions involving $10 \mathrm{M}$ hydrofluoric acid decreased the zirconium concentration in the dissolver product, increased the fluorideto-zirconium mole ratio, decreased the concentration of uranium in solution, and increased the stability (see Table II-A). This trend was noted to a lesser degree when using 4.8M hydrofluoric acid (see Table II-B).

Engineering design considerations suggest that the lower dissolvent feedrate-to-fuel-surface ratios shown in Table II, parts $A$ and $B$, may be used in continuous dissolver equipment proposed for the ICPP. For these slow feed rates the $4.8 \mathrm{M}$ hydrofluoric acid flow sheet appears to be more promising than the $10 \mathrm{M}$ acid flow sheet, because it produces dissolver products of greater stability with respect to solid formation and could dissolve alloy fuels of higher uranium content. Solutions were reported as unstable when any visible amount of solid was present. 
TABLE II

CONDITIONS ANI RESULTS FOR CONTIIUOUS LABORATOFY DISSOLUTICN OF ZIRCONIUM FUEL

\begin{tabular}{|c|c|c|c|c|c|c|c|c|c|c|c|c|c|}
\hline \multirow{3}{*}{$\begin{array}{l}\text { Run } \\
\text { No. }\end{array}$} & \multirow{3}{*}{$\begin{array}{l}\text { Dissolvent } \\
\text { Acid Feed } \\
\text { (M HF) } \\
\end{array}$} & \multirow{3}{*}{ Fuel (a) } & \multirow{3}{*}{$\begin{array}{l}\text { Fees- } \\
\text { to-F'se } \\
\text { Ratio(j) } \\
\text { (cm/́nin) } \\
\end{array}$} & \multirow[b]{2}{*}{$\begin{array}{l}\text { Dissolvent } \\
\text { Acid Flow } \\
\text { Direction }\end{array}$} & \multirow{2}{*}{$\begin{array}{c}\text { Disso- } \\
\text { lution: } \\
\text { Rate } \\
\text { (mg/cm } / \mathrm{cm}^{2} / \\
\text { min) } \\
\end{array}$} & \multirow[b]{2}{*}{$\begin{array}{l}\text { Temp. } \\
\left({ }^{\circ} \mathrm{C}\right)\end{array}$} & \multicolumn{3}{|c|}{$\begin{array}{c}\text { Dissolver } \\
\text { Product Analysis } \\
\end{array}$} & \multirow{2}{*}{$\begin{array}{c}\text { Fuel } \\
\text { Uranium } \\
\text { Conient } \\
\text { Dissoirable } \\
(\%, j) \\
\end{array}$} & \multirow{3}{*}{$\begin{array}{l}\text { \% of U } \\
\text { Lost to } \\
\text { Solids in } \\
\text { Bottom of } \\
\text { Dissolver }\end{array}$} & \multirow{2}{*}{$\begin{array}{c}\text { \% of U } \\
\text { Adhering } \\
\text { to } \\
\text { Dissolver } \\
\text { Walls } \\
\end{array}$} & \multirow{2}{*}{$\begin{array}{l}\text { Dissolver } \\
\text { Product } \\
\text { Stability } \\
\text { at } 23^{\circ} \mathrm{C} \\
\end{array}$} \\
\hline & & & & & & & $\stackrel{\mathrm{Zr}}{(\mathrm{M})}$ & $\begin{array}{l}\mathrm{F} / \mathrm{Zr} \\
\text { (Mole } \\
\text { Ratio) }\end{array}$ & $\begin{array}{c}U \\
(g / 1)\end{array}$ & & & & \\
\hline & & & & A. Study of & Upflow Di & ssolut1 & on wit & $\mathrm{h} 10 \mathrm{MI}$ & $F$ at 90 & & & & \\
\hline 3 & 10 & $\mathrm{zr}-2$ & 0.5 & upflow & 104 & 90 & 2.2 & 5.4 & - & - & - & - & stable > 1 mo \\
\hline 2 & 11 & $\mathrm{Zr}-2$ & 0.1 & upflow & 68 & 90 & 2.26 & $5 . \overline{2}$ & - & - & - & - & stable > 1 mo \\
\hline 4 & 10 & $\mathrm{Zr}-2$ & 0.2 & upflow & 66 & 90 & 2.23 & 5.2 & 一 & - & - & - & stable > 1 mo \\
\hline 5 & 10 & $\mathrm{Zr}-2$ & 0.2 & upflow & 37 & 90 & 2.25 & 5.2 & - & - & - & - & stable > I mo \\
\hline 7 & 10 & $240-2 r-2$ & 0.06 & upflon & 13 & 90 & 2.46 & 4.8 & 2.1 & 1.0 & - & - & unstable \\
\hline \multirow[t]{2}{*}{10} & 10 & $36 \mathrm{U}-2 \mathrm{r}-2$ & 0.612 & upflow & 5.1 & 90 & 2.53 & 4.5 & 3.5 & 1.5 & - & - & unstable at $92^{\circ}$ \\
\hline & \multicolumn{12}{|c|}{ B. Study of Upflow Dissolution with $4.8 \mathrm{M}$ HF at $50^{\circ} \mathrm{C}$} & \\
\hline 6 & $4.8(\mathrm{c})$ & $\mathrm{Zr}-2$ & 0.4 & upflow & 36 & 90 & 1.14 & 4.8 & - & - & - & - & stable > I mo \\
\hline 8 & 4.8 & $3-\mathrm{U}-\mathrm{Zr}-2$ & 0.06 & lipflow & 6.9 & 90 & 1.24 & 4.4 & 2.4 & $2 . z$ & - & - & sl. unstable \\
\hline 9 & 4.8 & $3 \div \mathrm{r}-2 \mathrm{r}-2$ & 0.56 & upflow & 7.1 & 90 & 1.2 & 4.4 & 2.5 & 2.1 & - & - & sl. unstable \\
\hline 11 & 4.8 & $3-2 r-2$ & 0.04 & upflow & 4.0 & 90 & 1.25 & 4.2 & 2.6 & 2.2 & 4.0 & 3.0 & sl. unstable \\
\hline \multicolumn{14}{|c|}{ C. Study of Dissolution with $4.8 \mathrm{M} \mathrm{HF}$ and Varying Temperatires and Flow Canditions } \\
\hline 13 & 4.8 & 39 U-2r-2 & 0.04 & downflow & 3.8 & 79 & 1.22 & 4.5 & 3.1 & 2.7 & 0.03 & 0.001 & $\begin{array}{l}\text { sl. unstable } \\
\text { after } 1 \text { mo }\end{array}$ \\
\hline 14 & 4.8 & 39. U-Zr-2 & 0.04 & recirculeted & 3.7 & ו & 1.19 & 4.4 & 2.9 & 2.6 & 0.03 & 0.003 & stable > $1 \mathrm{mo}$ \\
\hline 15 & 4.8 & $3 \mathrm{U}-\mathrm{Zr}-2$ & 0.04 & downflow & 3.5 & 92 & 1.06 & 5.4 & 1.5 & 1.5 & 0.5 & 6 & $\begin{array}{l}\text { sl. unstable } \\
\text { after } 8 \text { days }\end{array}$ \\
\hline 16 & 4.8 & $39 \mathrm{U}-\mathrm{Zr}-2$ & $0.0+4$ & domflow & 3.7 & 80 & 1.17 & 4.4 & 2.9 & 2.6 & 0.01 & 0.2 & $\begin{array}{l}\text { sl. unstable } \\
\text { after } 2 \text { days }\end{array}$ \\
\hline 17 & 4.8 & $3 \neq \mathrm{U}-\mathrm{Zr}-2$ & 0.04 & downflow & 3.8 & 60 & 1.19 & 4.3 & 3.3 & 2.9 & 0.005 & 0.08 & stable $>2$ wks \\
\hline 18 & 4.8 & $39=U-2 r-2$ & 0.04 & upflow & $3.7^{\circ}$ & 60 & 1.14 & 4.6 & 2.7 & 2.5 & 0.1 & 0.02 & $\begin{array}{l}\text { sl. unstable } \\
\text { after } 5 \text { days }\end{array}$ \\
\hline \multirow{2}{*}{\multicolumn{14}{|c|}{ 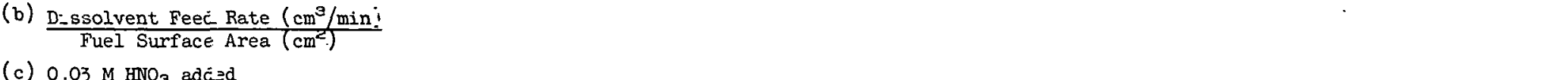 }} \\
\hline (c) & $0.03 \mathrm{M} \mathrm{HNO}_{3}$ & $\operatorname{adc}=d$ & & & & & & & & & & & \\
\hline
\end{tabular}


1.23 Uranium Dissolution Behavior. Under the conditions of runs 8,9, 10 , and 11 , solids containing uranium were found in the dissolver product solution, adhering to the walls of the dissolver, and at the bottom of the dissolver, because the uranium content of the fuel exceeded that which could be dissolved and retained in solution under the conditions of the run. Consequently, studies were made to determine whether uranium precipitation in the dissolver vessel could be decreased, and the concentration of dissolved uranium in the dissolver product increased by the use of downflow or recirculating dissolution, or by dissolution at lower temperatures. The results of this study are summarized in Table II-C and some of the data are depicted graphically in Figures 3 and 4.

The data of Figure 3 indicate that operation of the laboratory continuous dissolver, either upflow or downflow, resulted in a higher concentration of uranium in solution as the dissolution temperature was decreased; the rate of reaction was independent of temperature over the range studied, 60 to $92^{\circ} \mathrm{C}$, as shown in Table II-C. A moderate advantage was shown for downflow operation over upflow. Where the data were available, the amount of precipitated uranium remaining in the dissolver at the termination of the runs was measured and is plotted against temperature in Figure 4. The presence of less uraniun-containing solids in the dissolver at the lower temperature may be accounted for by a change in the nature of the solid phase. This difference in the solid phase may result in a change in solubility or in a change in its ability to adhere to the walls. Such is the case in simple batch dissolutions of uranium metal. Hydrolysis of the uranium tetrafluoride or colloid formation also may be involved. The difference in apparent uranium solubility, when the manner of operation of the dissolver is changed, is tentatively associated with varying degrees of local precipitation of uranium tetrafluoride in regions of high fluoride-to-zirconium mole ratio. Figure 1 of the previous section

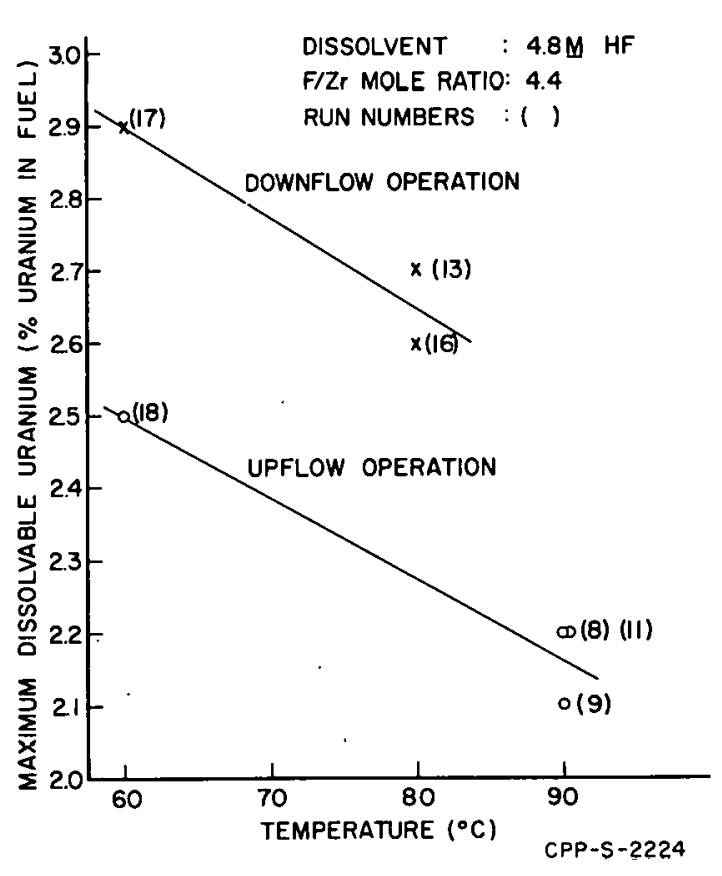

Fig. 3 Influence of temperature and direction of acid flow on dissolution of uranium in Zircaloy-2-uranium fuel.

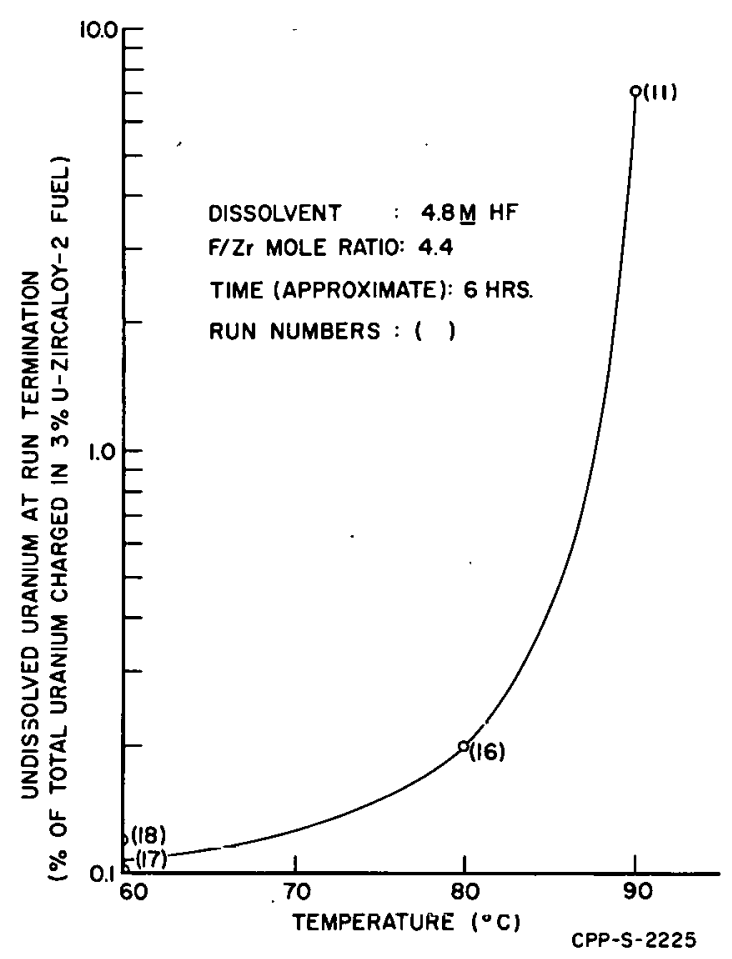

Fig. 4 Effect of temperature of dissolution on uranium residue left in dissolver. 
shows how sharply the solubility varies with the fluoride and zirconium concentration of the solution. The fact that the observed solubility of uranium in the continuous dissolver effluent generally exceeds the equilibrium values may well be utilized in continuous dissolver operation to extend the applicability of the flow sheet to fuels more rich in uranium or to provide additional safety factors towards uranium precipitation. Complete solubility of uranium from 2 per cent uranium alloys is obtained for all temperatures and conditions.

The fuel used in the experiments reported in Figures 3 and 4 contained approximately 2.9 per cent uranium.

1.24 Corrosion. Welded Monel and Carpenter-20 (Cb) test coupons were present in the dissolver outlet line during the runs shown in Table II-A and B. The coupons had been exposed to dissolver product resulting from the dissolution of Zircaloy-2 or uranium-Zircaloy-2 alloy in the following solutions: $4.8 \mathrm{M}$ hydrofluoric acid for 18.8 hours, $4.8 \mathrm{M}$ hydrofluoric acid-0.03 nitric acid for 2.8 hours, and $10 \mathrm{M}$ hydrofluoric acid for $\overline{24}$. 4 hours at 80 to $90^{\circ} \mathrm{C}$. The corrosion pentration resulting from the total 46-hour exposure to dissolver product was determined to be 4.9 and 0.2 mils per month for the Monel and Carpenter-20 (Cb) coupons, respectively. No visible corrosion was noted within the Monel dissolver.

\subsection{Continuous Zirconium Fuel Dissolution in the Pilot Plant. (D. K. MacQueen,} Problem Leader; H. V. Chamberlain, A. P. Roeh)

Preliminary tests of continuous zirconium dissolution in miniature dissolvers were reported in the previous quarter [1]. Evaluation of the results of those tests indicated that a dilute dissolvent flow sheet $(4.8 \mathrm{M}$ HF dissolvent) in a Monel system showed the most promise for a continuous zir conium headend.

In the current period, extended pilot plant runs were made at approximately $200^{\circ} \mathrm{F}$, and the temperature was maintained by the heat of reaction in the equipment used, rather than at the controlled lower temperature indicated to be preferable in the laboratory experiments discussed in the preceding section. This choice was originally made because of the desire to avoid, if possible, the serrous design problem of heat removal from the highly exothermic reaction. The solids buildup at higher temperatures, which was indicated to be a potential problem in six-hour laboratory runs, was not serious in extendèd runs using the $4.8 \mathrm{M} \mathrm{HF}-0.03 \mathrm{M} \mathrm{HNO}_{3}$ flow sheet. The solids reached an equilibrium state with small amounts leaving in the effuluent and a film being maintained in the dissolver vessel.

Variations of the dilute hydrofluoric acid dissolvent process were tested in one-half-inch ID miniature dissolvers in an effort to minimize the solids produced during dissolution of two weight per cent uranium-zirconium fuel. The first test was made using a $4.8 \mathrm{M} \mathrm{HF}$ feed with downflow of the dissolvent in the dissolver. The second test used a $4.8 \mathrm{M}$ HF feed with upflow of the dissolvent in the dissolver. The third test used a $4.8 \mathrm{M} \mathrm{HF}-0.03 \mathrm{M} \mathrm{HNO}_{3}$ feed with upflow of the dissolvent in the dissolver. The first and third tests were run for 190 hours and the second test for 80 hours; all were run at a dissolvent feed rate of three milliliters per minute, giving a nominal retention time of 18 minutes in the dissolver.

The dissolver effluent from the first test contained a substantial quantity of solids, and the dissolver itself was found to be heavily loaded with solids at the completion of the test. The major constituent of the solids in the effluent was tin, but zirconium was the major constituent of the solids remaining in 
the dissolver. Both contained less than 10 per cent uranium. Although the uranium behavior in this test was very good, the large quantity of solids produced discourages further consideration of the downflow dissolver.

The quantities of solids entrained in the dissolver effluent and remaining in the dissolver from the second test were much less than those in the first test; however, these solids were composed principally of uranium (25 to 50 per cent). The amount of solids in the dissolver at the completion of the two runs is not directly comparable, because the second test was run for only 80 hours, while the first test was run for 190 hours. The second test was not restarted after a scheduled shutdown at the end of 80 hours, because the quantity of solids produced during the test was above an acceptable level.

Good results were obtained during the third test with the addition of $0.03 \mathrm{M}$ $\mathrm{HNO}_{3}$. Very few solids were present in the dissolver effluent, and the dissolver itself contained no solid accumulations, although there was a thin film of precipitate on the dissolver wall near the bottom and on the feed inlet pipe. Although the solids and precipitate film were composed mainly of uranium, in the form of $\mathrm{UF}_{4} \cdot 3 / 4 \mathrm{H}_{2} \mathrm{O}$, the total quantity of solids produced was quite low and appeared to have reached an equilibrium. This dissolvent appears very promising for continuous zirconium dissolution at the ICPP.

An additional test is in progress, using the $4.8 \mathrm{M} \mathrm{HF}-0.03 \mathrm{M} \mathrm{HNO}_{3}$ flow sheet in an upflow dissolver. The fuel charge in this test consists of a mixture of Zircaloy with 5.25 per cent uranium alloy fuel pieces and sufficient additional Zircaloy pieces to produce an average of two per cent uranium in the total charge. This test should determine any local effects that may occur with a uranium content in a fuel "meat" section considerably greater than the overall percentage of uranium in the fuel element.

\section{AQUEOUS ALUMINUM FUEL REPROCESSING}

2.1 Effect of High Silicon Content in Reprocessing of Aluminum Alloys (H. T. Hahn, Problem Leader; M. R. Bomar, S. J. Horn, D. L. Bauer)

The General Electric Test Reactor (GETR) fuel is representative of aluminum clad-aluminum uranium alloy fuels wherein the meat contains about two per cent silicon to improve the metallurgical properties of the alloy. In addition to the surfactant properties of the silica produced upon dissolution, which frequently represents an operational problem, there has been concern that the enriched uranium might be associated with the silicon in the fuel in an insoluble intermetallic compound, or that soluble uranium might be irreversibly adsorbed on the silica after dissolution. The effect of this silicon content upon the chemical reprocessing of such fuels has been investigated on a laboratory scale using fuel plates furnished by the fuel manufacturer. The clad plates were dissolved batchwise, the dissolver product solution digested at the boiling point or allowed to stand at room temperature to age the silica, and the solution extracted in a small pulsed column to determine extraction loses and column behavior.

The following results were obtained from the laboratory studies:

(1) No insoluble, metallic, uranium-bearing residue was found 
in the dissolver effluent after normal batch dissolution in mercurycatalyzed nitric acid.

(2) No evidence of selective concentration of uranium was found in the silica slurry.

(3) Siliceous residues were produced which occluded uranium, but from which the uranium could be recovered without unusual loss by solvent extraction with $3-1 / 4$ per cent tributyl phosphate in Amsco, the process extractant.

(4) Freshly prepared silica-bearing feeds increased interfacial emulsion in the column as compared to aqueous feeds containing no silica, but uranium losses to the raffinate were not adversely affected. Emulsification was particularly notable with one feed which had been gelatin treated.

These small scale experiments did not reveal any unusual problems in connection with the processing of the alloy fuels containing two per cent silicon in the meat; however, pilot plant or plant scale experiments will be required to definitely prove that there are no long-term problems. 


\section{I. ELECTROLYTIC DISSOLUTION SYSTEMS}

(Section Chief: K. L. Rohde)

1. CORROSION RATE OF STAINLESS STEEL

IN ELECTROLYTIC DISSOLVER SOLUTIONS

(H. T. Hahn, Problem Leader, J. R. Aylward)

It has been observed that the corrosion of type 304 stainless steel process equipment in electrolytic dissolver solutions (nitrate system) can be excessive when a large amount of $\mathrm{Cr}^{+6}$ is present in solution. This is due, for the most part, to the $\mathrm{Cr}^{+6}-\mathrm{Cr}^{+3}$ couple which, under some conditions, has a sufficiently positive potential and displays sufficiently favorable kinetics to maintain a mixed potential in the transpassive region of the steel. Nitric acid reduction also contributes to the corrosion, although probably to a lesser extent.

Electrolytic dissolution of stainless steel produces $\mathrm{Cr}^{+6}$ at the anode, but the reduction products of nitric acid $\left(\mathrm{NO}_{2}\right.$, etc) formed at the cathode reduce $\mathrm{Cr}^{+6}$ to $\mathrm{Cr}^{+3}$ in solution, so that normally the chromium in these dissolver product solutions is mostly in the trivalent state. At temperatures approaching the boiling point the low solubility of the reduction product gases hinders the reduction of $\mathrm{Cr}^{+6}$ to $\mathrm{Cr}^{+3}$ and the kinetics become favorable for the oxidation of $\mathrm{Cr}^{+3}$ to $\mathrm{Cr}^{+6}$ by the nitric acid. In this way, high temperatures may produce dissolver solutions which are corrosive to stainless steel equipment.

The number of parameters affecting the corrosiveness of these solutions is so numerous that a determination of the corrosion rate for each solution composition over the temperature range needed would be an impossible task. From work carried out in this laboratory on the electrolytic dissolution of stainless steel [8] it was found that the dissolution rate of type 304 stainless steel at low current densities and at constant potential is a function only of temperature and total nitrate ion concentration. Unfortunately these data at low current densities do not represent the steady state corrosion rate because the current was measured after only one minute at a given potential, whereas the corrosion rate reaches a steady state over a period of hours. (At higher current densities the steady-state is reached quicker so that the one minute interval is sufficient above $10^{-3} \mathrm{amp} / \mathrm{cm}^{2}$. This was the region of most concern in the electrolytic dissolution work.) Even though the corrosion rates calculated from the dissolution studies are too high, the dependence on solution composition and temperature should be the same.

Since the potential-current density relationship for the anodic (corrosion) reaction is a function only of the temperature and the nitrate ion concentration, a limited number of experiments will be sufficient to determine the corrosion rate, provided the potential of the stainless steel in the solution is measured. This will be the potential at which the sum of the cathodic reaction rates equals the anodic (corrosion) reaction rate. Therefore, all the parameters affecting the cathodic part of the reaction will be combined and determined by a single potential measurement once the rate of the anodic reaction is known.

Experiments are being conducted to determine the steady-state corrosion rate of type 304 stainless steel as a function of potential, temperature, and solution composition. For the first series, a typical dissolver solution containing 
$1 \mathrm{M} \mathrm{HNO}_{3}$ plus $4 \mathrm{MNO}_{3}^{-}$from $\mathrm{Fe}^{+3}$ and $\mathrm{Ni}^{+2}$ nitrates was used. Chromium (VI)* was added in the form of $\mathrm{CrO}_{3}$. These cations were used in the ratio found in stainless steel ( 74 per cent $\mathrm{Fe}, 18$ per cent $\mathrm{Cr}, 8$ per cent $\mathrm{N}$ ).

The electrodes were 304 stainless steel in sheet form with an area of 100 square centimeters exposed to the solution. They were cleaned before use by anodic etching in $6 \mathrm{M} \mathrm{HNO}_{3}$ followed by washing in distilled water. A new electrode and solution were used for each experiment. All potentials were measured with respect to a saturated calomel electrode at $25^{\circ} \mathrm{C}$.

A number of procedures are being used to determine the steady-state potential-corrosion rate relationships and their dependence on temperature:

(1) Weight loss and current measured at constant potential and temperature.

(2) Current vs temperature at constant potential.

(3) Potential vs tempcraturc at constant current.

(4) Potential at constant current and temperature.

Procedure 1 is the standard and reliable method but is time-consuming. The other methods are rapid but give correct results only when the steady state is reached quickly and the current efficiency is 100 per cent. These two conditions are approached at potentials removed from the corrosion potential (high current densities). To date the potential-corrosion rate relationships for a $5 \mathrm{M}$ nitrate ion concentration have been established using methods 1,2 , and $\overline{3}$, above, for $25^{\circ} \mathrm{C}$ and $85^{\circ} \mathrm{C}$. The results are indicated in Figure 5.

Assuming a constant heat of activation $\left(\mathrm{H}^{\ddagger}\right)$, over this temperature range**, the potential-corrosion rate curves at intermediate temperatures can be calculated from the equation

$$
\left(\frac{\partial \ln I}{\lambda . T / T}\right)_{L^{\prime}}=-\frac{\Delta \dot{H}^{\ddagger}}{R}
$$

In this way a plot of potential vs temperature for constant corrosion rates of $0.4,2$, and 10 mils per month was constructed and is shown in Figure 6 . With this information a simple potential and temperature measurement is sufficient to determine the instantaneous corrosion rate of stainless steel equipment in any dissolver solution provided the nitrate ion concentration is $5 \mathrm{M}$. For example, with the solution used in this work $\left(1 \mathrm{M} \mathrm{HNO}_{3}+4 \mathrm{M} \mathrm{NO}_{3}^{-}\right.$from $\mathrm{Fe}^{+3}$, $\mathrm{Ni}^{+2}$, and $\mathrm{Cr}^{+6}$ ) the corrosion potential was found to be 1.002 volt and independent

* Steady-state rates are attained more rapidly when $\mathrm{Cr}^{+6}$ is used rather than $\mathrm{Cr}+3$ and the corrosion potential is at its maximum value.

** Experiments at $55^{\circ} \mathrm{C}$ are planned to check the validity of this assumption. 


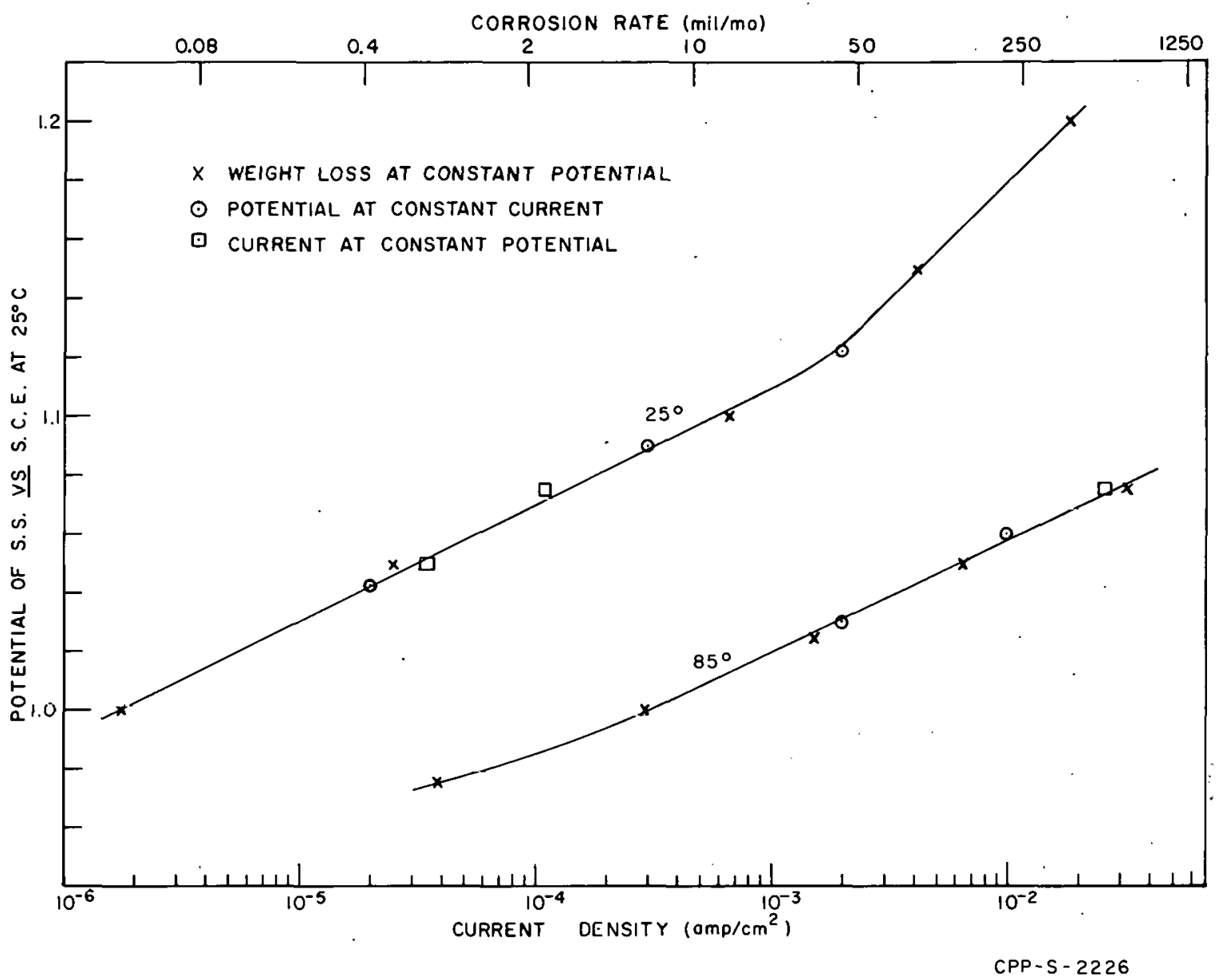

Fig. 5 Potential-current density (corrosion rate) relationships for type 304 stainless steel at 25 and $85^{\circ} \mathrm{C}$ in a dissolver solution containing $5 \mathrm{M} \mathrm{HNO}_{3}$.

of temperature. With reference to Figure 6 , only at temperatures above $70^{\circ} \mathrm{C}$ would the corrosion rate be greater than two mils per month. It should be noted that the corrosion potential would have a different value at other concentrations of $\mathrm{Cr}^{+6}, \mathrm{H}^{+}$, $\mathrm{NO}_{3}{ }^{-}$and dissolved nitrogen oxides.

From the electrolytic dissolution studies [8] it was found that, at constant current density, the anodic potential shifts to more positive values with increasing nitrate ion concentration,

$$
\left(\frac{\partial E}{\partial \log \left(\mathrm{NO}_{3}{ }^{-}\right)}\right)_{I, T}=+0.183 \text { volt }
$$

This amounts to about $+15 \mathrm{mv}$ in going from 5 to $6 \mathrm{M} \mathrm{NO}_{3}-$ so that in a solution containing $\overline{6 \mathrm{M}} \mathrm{NO}_{3}^{-}$the curves in

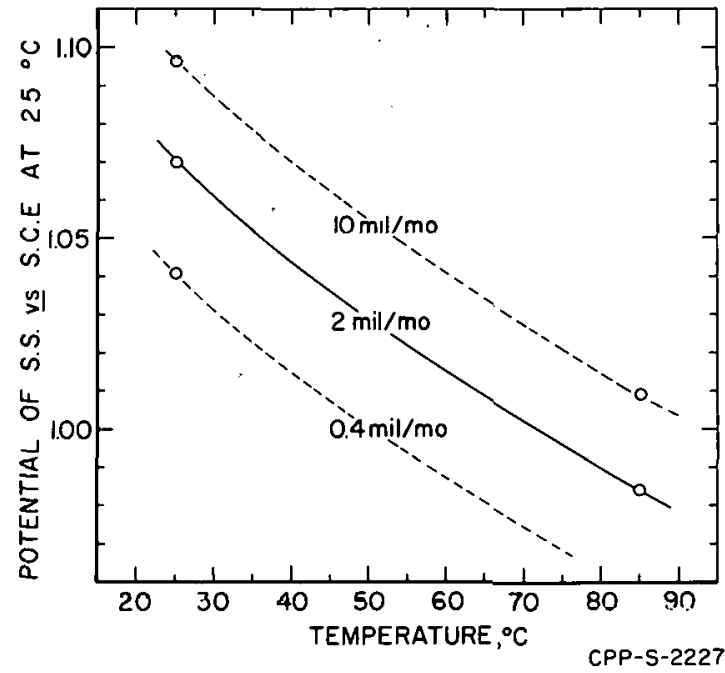

Fig. 6 Corrosion rates as functions of potential and temperature for type 304 stainless steel in a dissolver solution containing $5 \underline{M}$ $\mathrm{HNO}_{3}$.

Figure 6 would be displaced $15 \mathrm{mv}$ in the positive direction. This value should be considered as tentative until it is checked under steady-state conditions. 
In cases where stainless steel process equipment must handle these solutions at high temperatures, eg evaporators, cathodic protection could be used to restrict the potential to safe values. The curves shown in Figure 6 are useful in determining the exact amount of cathodic protection necessary. They of course may also be used to monitor the instantaneous corrosion rate of specific regions encountered by the electrolytic dissolver process stream.

2. ELECTROCHEMISTRY OF TYPE 304

STAINLESS STEEL IN NITRATE SOLUTIONS

(H. T. Hahn, Problem Leader; J. R. Aylward, E. M. Whitener)

A topical report [8] on the electrolytic dissolution of type 304 stainless steel has been completed. Pertinent conclusions are summarized as follows:

(1) The characteristics of the polarization curves were found to be quite varled with regions of 'l'atel behavior, secondary passivation, and in some cases, a limiting current density. These factors are greatly dependent on solution composition and temperature. The Tafel relationship $(E=a+b \log I)$ is obeyed at current densities $<10^{-3} \mathrm{amp} / \mathrm{cm}^{-2}$. Secondary passivation occurs in the medium current density range at low hydrogen and nitrate ion concentrations, and low temperatures. A limiting current density ( 1 amp/cm-2) is observed at nitric acid concentrations above $6 \mathrm{M}$. The value of the limiting current density increases with increasing temperature and decreasing nitric acid concentration.

(2) Efficient anode operation over a wide range of solution compositions is possible at temperatures above $60^{\circ} \mathrm{C}$. At this temperature or higher, secondary passivation, limiting currents, and gas evolution (at anode) are avoided at the current densities ( 0.1 to $2 \mathrm{amp} / \mathrm{cm}^{-2}$ ) and product solution compositions that normally would be encountered in dissolver operation.

\section{ELECTROLYTIC DISSOLVER PRODUCT ANALYZER}

(H. T. Hahn, Problem Leader; D. P. Pearson)

An inline analysis of electrolytic dissolver product solutions would furnish a rapid means of adjusting the dissolver to desirod opcrating conditions. The basis for simultaneously determining both the stainless steel nitrate and the nitric acid concentrations from electrical conductance measurements was outlined previously [9]. The principle of operation involves simultaneous determination of the conductance of two samples of the process solution, one at full concentration and the second diluted one-to-one with water. Development of the method has proceeded to a point of constructing an enclosed glass apparatus. Flows are controlled by gravity instead of the low-volume metering pumps which were initially proposed. After calibration the unit will be used in conjunction with the flow sheet dissolver development program. 
A schematic drawing of the instrument is shown in Figure 7. The flow rates of the solution (A) and water (B) streams are governed by the streams' passages through capillary tubes (C) under a fixed hydrostatic head (D). Thus, the volume ratio of the two streams will depend on their densities and viscosities, which in turn depend on temperature and solution composition. If the temperatures (E) of the streams a re controlled, the composition of the mixed solution will be reproducible. The mixing chamber is shown at (F) and the conductance cells are shown

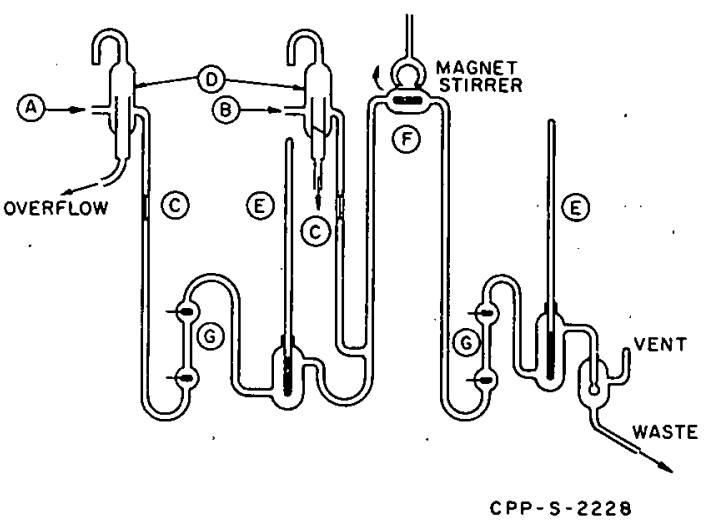

Fig. 7 Inline conductance analyzer. at (G).

The first material to be studied in the one-tenth scale electrolytic dissolver will be Nichrome; therefore, calibration of the unit with standard Nichrome $(80-20)$ solutions has been begun in order to determine whether the unit will be capable of anlyzing this type of solution.

\section{NON-METALLIC MATERIALS OF} CONSTRUCTION IN ELECTROLYTIC SYSTEMS (R. D. Fletcher, Problem Leader, L. A. Decker)

Preliminary Chemical Tests. A number of plastic and plastic-glass laminate materials have shown excellent resistance to boiling electrolytic dissolver product solution (1M nitric acid-75 g/1 stainless steel components as the nitrates); however, it was recognized that these same materials might be very sensitive to attack by boiling nitric acid. A survey was made of the behavior of the preferred plastic materials in $8 \mathrm{M}$ nitric acid at the boiling point to determine the extent of the damage which might occur in pure nitric acid. The results are shown in Table III. The drastic damage experienced in these tests must be avoided, but this probably can be accomplished in practice since the dissolver will operate containing a solution at the steadystate dissolver product composition. Fresh reagent will be fed into the recirculating dissolver solution stream in the external loop.

Irradiation Tests. In continuing the irradiation tests in boiling dissolver product solution, a number of plastic materials and ceramic alumina are being irradiated in the MTR gamma facility at a dose rate of $1 \times 10^{7} \mathrm{R}$ per hr. Current results are given in Table IV. All samples which resist the lower radiation dosages will be finally examined after an expusure to $1010 \mathrm{R}$. 
TABLE III

CHANGES IN PLASTICS SAMPLES AFTER BOILING IN NITRIC ACID

\begin{tabular}{|c|c|c|c|c|}
\hline \multirow[b]{2}{*}{ Material } & \multirow{2}{*}{$\begin{array}{l}\text { Exposure } \\
(\mathrm{hr})\end{array}$} & \multicolumn{2}{|c|}{ Change after Boiling } & \multirow[b]{2}{*}{$15.7 \mathrm{M} \mathrm{HNO}_{3}$} \\
\hline & & $6 \mathrm{M} \mathrm{HNO}_{3}$ & $8 \mathrm{M} \mathrm{HNO}_{3}$ & \\
\hline G-7 (Taylor Fiber Co.). & 336 & $8 \%$ wt loss & $8 \%$ wt loss & $\begin{array}{l}8 \% \text { wt loss (slight } \\
\text { delamination) }\end{array}$ \\
\hline G-7 (Insulation Mfr. Corp.) & 168 & & $10 \%$ wt loss & \\
\hline G-7 (Mica Insulator)(a) (fine weave) & 168 & & $13 \%$ wt loss & \\
\hline $\begin{array}{l}\text { G-7 } \\
\text { (Mica Insulator) }(\text { a) } \\
\text { (course weave) }\end{array}$ & 168 & & $\begin{array}{l}14 \% \text { wt loss, slight } \\
\text { delamination }\end{array}$ & \\
\hline $\begin{array}{l}\text { Marlex (b) (white) (Phillips } \\
\text { Petroleum Co.) }\end{array}$ & 168 & & $\begin{array}{l}7 \% \text { wt loss, severe } \\
\text { surface cracks }\end{array}$ & - \\
\hline $\begin{array}{l}\text { Marlex (b) (black) (Phillips } \\
\text { Petroleum Co.) }\end{array}$ & 168 & & $\begin{array}{l}8 \% \text { wt loss, severe } \\
\text { surface cracks }\end{array}$ & \\
\hline Penton (Polymer Corp. of Penn.) & 168 & & $\begin{array}{l}>20 \% \text { wt loss, } \\
\text { brittle-crumbled }\end{array}$ & $=$ \\
\hline Lexan (Standard Polymer, Inc.) & 168 & & $37 \%$ wt loss & \\
\hline $\begin{array}{l}\text { (a) Division of Minnesota Mining and } \\
\text { (b) A registered trademark of Philli }\end{array}$ & Manufact & ing Co. & $f$ & \\
\hline
\end{tabular}

\section{TABLE IV}

VISIBLE CHANGES IN PLASTICS SAMPLES AFTER GAMMA IRRADIATION $\begin{array}{ll}\text { Conditions: } & 1 \text { M nitric acid, } 75 \mathrm{~g} / 1 \text { stainless steel components, } 214^{\circ} \mathrm{F}, \\ & \text { irradiation rate }=1 \times 10^{7} \mathrm{R} / \mathrm{hr} .\end{array}$

\section{Material}

Penton (Polymer Corp. of Penn.)

Lexan (Standard Polymer, Inc.)

Lexan (Standard Polymer, Inc.)

G-7 (Insulation Mi'r. Corp.)

G-7 (Mica Insulator)(a) (fine weave)

G-7 (Mica Insulator)(a) (course weave)

Marlex(b) (white) (Phillips Petroleum Co.) Marlex(b) (black) (Phillips Petroleum Co.)

'96\% Alumina (McDanel Refractory Porcelain Co.) 99\% Alumina (McDanel Refractory Porcelain Co.)
Appearance after Irradiation to $1 \times 10^{8} \mathrm{R}$

brittle, split brittle, darkened

$$
\text { to } 1 \times 10^{9} \mathrm{R}
$$

disintegrated, swolion

slightly yellowed, no delamination, no dimensional change

$$
\text { to } 2.2 \times 10^{9} \mathrm{R}
$$

darkened

no apparent change no apparent change no apparent change

(a) Division of Minnesota Mining and Manufacturing Co.

(b) A registered trademark of Phillips Petroleum Co. for its family of polyolefin resins. 


\section{NEW WASTE TREATMENT METHODS}

(Section Chief: K. L. Rohde, Chemistry)

\section{DISPOSAL OF LOW-LEVEL RADIOACTIVE WASTES \\ (D. W. Rhodes, Problem Leader; M. W. Wilding)}

Laboratory investigations were continued on the use of locally available natural earth materials as potential ion exchangers for the removal of strontium, cesium, and tritium from low-level radioactive wastes at the NRTS. A total of 14 earth materials was tested this period.

\subsection{Adsorption of Strontium and Cesium}

Of those tested, the earth material having the best characteristics for cesium and strontium removal had a high content of the mineral clinoptilolite. The strontium distribution coefficient (g Sr per $\mathrm{g}$ solid/g Sr per ml solution) for this material was about 5000 at a pH of 8 to 9 ; the cesium distribution coefficient was about 4000 at a $\mathrm{pH}$ of 6 and exceeded 1000 over the entire $\mathrm{pH}$ range from 2 to 10 . The broad $\mathrm{pH}$ range, over which the cesium-removal capability of this material is high, is a distinct advantage over other materials tested, and apparently would eliminate the need for $\mathrm{pH}$ adjustment of the waste solution.

For most materials tested, maximum strontium removal occurred at pH 8 to 10 and maximum cesium removal occurred at a pH of about 6 . Of the eight materials having maximum strontium distribution coefficients greater than 1000, six also had maximum cesium distribution coefficients greater than 1000 .

\subsection{Adsorption of Tritium}

The measured tritium capacity of a lignitic material and of a material high in clinoptilolite (both oven-dried at $110^{\circ} \mathrm{C}$ ) was about 0.03 bed volume of a waste solution containing $0.0153 \mu \mathrm{c} / \mathrm{ml}$. Although this value is negligible compared to the capacity of these materials for cations such as cesium and strontium, it does indicate that some exchange of tritium is occurring with adsorbed water, water of hydration, or by ion exchange. The amount of tritium removed was too great to be accounted for by dilution with reșidual moisture in the oven-dry material. 


\section{WASTE CALCINATION DEVELOPMENT AND DEMONSTRATION (Section Chiefs: K. L. Kohde, Chemistry; J. I. Stevens, Development Engineering)}

Laboratory and pilot plant studies of the fluidized bed calcination process for reduction of high-level wastes to a granular, free-flowing solid have been underway at the ICPP for several years. Early studies were conducted in 3-inch and 6-inch-diameter units; currently, a 12-inch-diameter, electrically heated unit and a 24-inch-square, NaK-heated unit are used for pilot plant studies with non-radioactive material. A 48-inch-diameter Demonstrational Waste Calcining Facility (DWCF) has been built for demonstration of this process with full-level wastes; cold testing of the DWCF is underway.

Although exploratory studies demonstrated the feasibility of this process for stainless steel and zirconium fuel wastes, the majority of the work has been with aluminum fuel wastes. A typical waste of this type contains $1.74 \mathrm{M}$ aluminum nitrate, $0.6 \mathrm{M}$ nitric acid, $0.01 \mathrm{M}$ mercuric nitrate, $0.04 \mathrm{M}$ sodium nitrate, fission products, and other minor components.

Feed rates from 5 to 150 liters per hour per air-atomizing nozzle have been used in pilot plant units with no perceptible tendency toward caking; capacity of all units has been limited by the rate of heat introduction through internal surfaces. Measured heat transfer coefficients range from 40 to 110 $\mathrm{BTU} /(\mathrm{hr})\left({ }^{\circ} \mathrm{F}\right)\left(\mathrm{ft}^{2}\right)$, depending upon bed particle size and fluidized bed density.

Particle size has been controlled by varying the atomizing air rate, the major factor governing particle attrition; quantitatively this effect is very dependent on the crystalline form of alumina produced. Various operating factors make significant differences in the rate of conversion of amorphous alumina calcine to the alpha (or, in isolated cases, gamma or iota) cyrstalline form. Particle attrition increases with alpha alumina content; hence, average bed particle size decreases and particle elutriation rate increases with increasing alpha content. High-alpha-content beds are more dense and contain less nitrate, both desirable features. Sodium is a necessary feed ingredient for alpha alumina formation; its effect can be overcome by addition of boric acid to the feed. Addition of one of these components to the feed is recommended to obtain the desired product form.

Intra-particle porosity varies from 5 to 60 per cent and is a direct function of bed temperature (from 250 to $550^{\circ} \mathrm{C}$ ) and feed concentration (from 0.8 to $2.0 \mathrm{M}$ aluminum), but not a significant function of any other variable. Superficial fluidizing velocities from 0.5 to 2.5 feet per second have been used; best results are obtained with velncities under 1.0 foot per eөoond.

Studies have been made with and without condensing the off-gas stream and with near-total recycle of non-condensible off-gas for fluidization. The latter method of operation shows promise for minimizing atmospheric contamination.

Operation of the DWCF this period showed good mechanical operability and close control over the process, the principal remaining problem being excessive solids carry-over past the primary cyclone. Pilot plant studies were conducted in connection with this problem to obtain additional data on solids elutriation from a fluidized bed. 
Preliminary laboratory studies indicated the formation of two intermediate compounds during calcination of stainless steel wastes.

\section{OPERATION OF THE DEMONSTRATIONAL WASTE CALCINING FACILITY (DWCF)}

(L. T. Lakey, Problem Leader; G. E. Lohse, P. N. Kelly)

Several changes were made in the DWCF equipment to correct previously detected deficiencies. A continuous operation period, run 6, of 250 hours verified improved operability due to some of these changes and gave detailed data concerning remaining deficiencies.

\subsection{Analysis and Correction of NaK Tube Vibration (S. D. Anderson, W. L. Fouts, H. H. Conley)}

A stress analysis was made on the NaK heat exchanger bayonet tube bundle following two tube failures [1] which resulted in helium leaks. A vibration analysis was performed on the unsupported tube bundle using 10 microdot stainless steel-clad, mineral-oxide-insulated strain gages. This analysis indicated that the tubes were undergoing cyclical deflections which caused strain at the tube-to-tubesheet weld as high as 620 microinches per inch: If continuously sustained, such a dynamic strain, coupled with thermal stresses, created a situation in which the calculated tube lifetime was only five hours. A stress analysis made after installation of a tube support indicated the strains were reduced to below 62 microinches per inch. Unlimited service life, from the fatigue standpoint, is indicated by this analysis. No additional difficulty from stress in the NaK tube bundle is anticipated.

\subsection{Feed Control}

Electromagnetic flowmeters were installed to eliminate feed rate fluctuations. The flow rate to each nozzle is now controlled and recorded, and a very steady feed rate is usually achieved. Stabilization of process temperatures and generally improved control over the entire process are secondary results of this modification.

\subsection{Solids Carry-over}

During this period, 10 of 16 Multiclone elements of the primary cyclone were closed off to increase the pressure drop to four inches of water at maximum gas flow in an effort to get better solids separation. As a result, solids carryover past the primary cyclone was reduced on run 6 to 20 pounds per hour from the 32 pounds per hour experienced on run 5. This carry-over, approximately one-third of the theoretical product rate, is considered excessive, however, and considerable effort is being expended through pilot plant and other studies to improve this situation. Attendant scrub solution concentrations on run 6 reached 20 grams per liter undissolved solids, 2.4 $\underline{\mathrm{M}}$ aluminum, and $0.7 \mathrm{M}$ boron, all undesirably high.

\subsection{Process Control}

Feed simulating the contents of waste tank WM-185, with $0.05 \mathrm{M}$ boric acid added, was introduced into the calciner for the first 142 hours of run 6. 
Scrub solution was not recycled to the feed to permit a better analysis of the primary cyclone performance. During this initial operating period, the alpha alumina content of the product dropped from approximately 20 per cent to 5 per cent. After boric acid was removed from the feed, no further change in the alpha alumina content of the product was apparent. The bulk density dropped from 1.20 to $1.02 \mathrm{~g} / \mathrm{cc}$ during addition of the boric acid, and continued to drop to $1.00 \mathrm{~g} / \mathrm{cc}$ at the end of the run. The mass median particle diameter increased throughout the run from 0.4 to 0.7 millimeter. These properties, and all others, were typical of amorphous alumina calcine production.

Caking occurred to a limited extent around all feed nozzles in the calciner on the last run. Small cakes $(\sim 1 / 2$ in. diameter) were found in the primary cyclone and larger cakes $(\sim 3$ in. diameter) were found in the quench drum. The vessel off-gas filter failed twice from contact with moisture, apparently due to condensation in vessel vent lines. Corrention of these diffioultics will be included among the objectives for the nexl DWCF operating period. Another objective of the next operation period will be to test a pneumatically motivated solids transport system to eliminate the need for the transport air blowers, which never have performed satisfactorily.

\section{PILOT PLANT DEVELOPMENT}

(L: T. Lakey and B. M. Legler, Problem Leaders; B. P. Brown, J. E. Arnold)

\subsection{Solids Carry-over}

The two-foot-square pilot plant calciner was operated to obtain data relevant to the principal remaining problem at the DWCF, namely, excessive carry-over of solids from the fluidized bed. Two runs (26 and 27A) were made to determine the effect of various feed and atomizing nozzle air rates on solids carry-over.

Detailed solids carry-over data obtained on these runs are shown in Tahle. $\mathrm{V}$ where they are compared to similar data from an earlier run, 25.

Conclusions regarding solids carry-over based on these runs are:

(1) Solids carry-over from the calciner is highly dependent upon the liquid feed rate and the nozzle air rate. Although precise correlations cannot. be obtained from the limited data, there are indications that the rate of fines production can be minimized for a practical feed rate by the proper selection of nozzle operating conditions.

(2) Solids carry-over from the calciner increases rapidly as the alpha alumina content of the bed increases; however, the solids loading in the scrub solution, ie, carry-over from the cyclone, remains nearly constant. This indicates that the extremely fine material escaping from the cyclone is produced in about equal quantities for either high or low alpha alumina content particles.

(3) Solids carried over from the calciner largely appear to be freshly formed alumina originating from the outer layer of the bed particles. This is substantiated by the negligible solids 
SOLIDS CARRY-OVER IN THE TWO-FOOT-SQUARE CALCINER

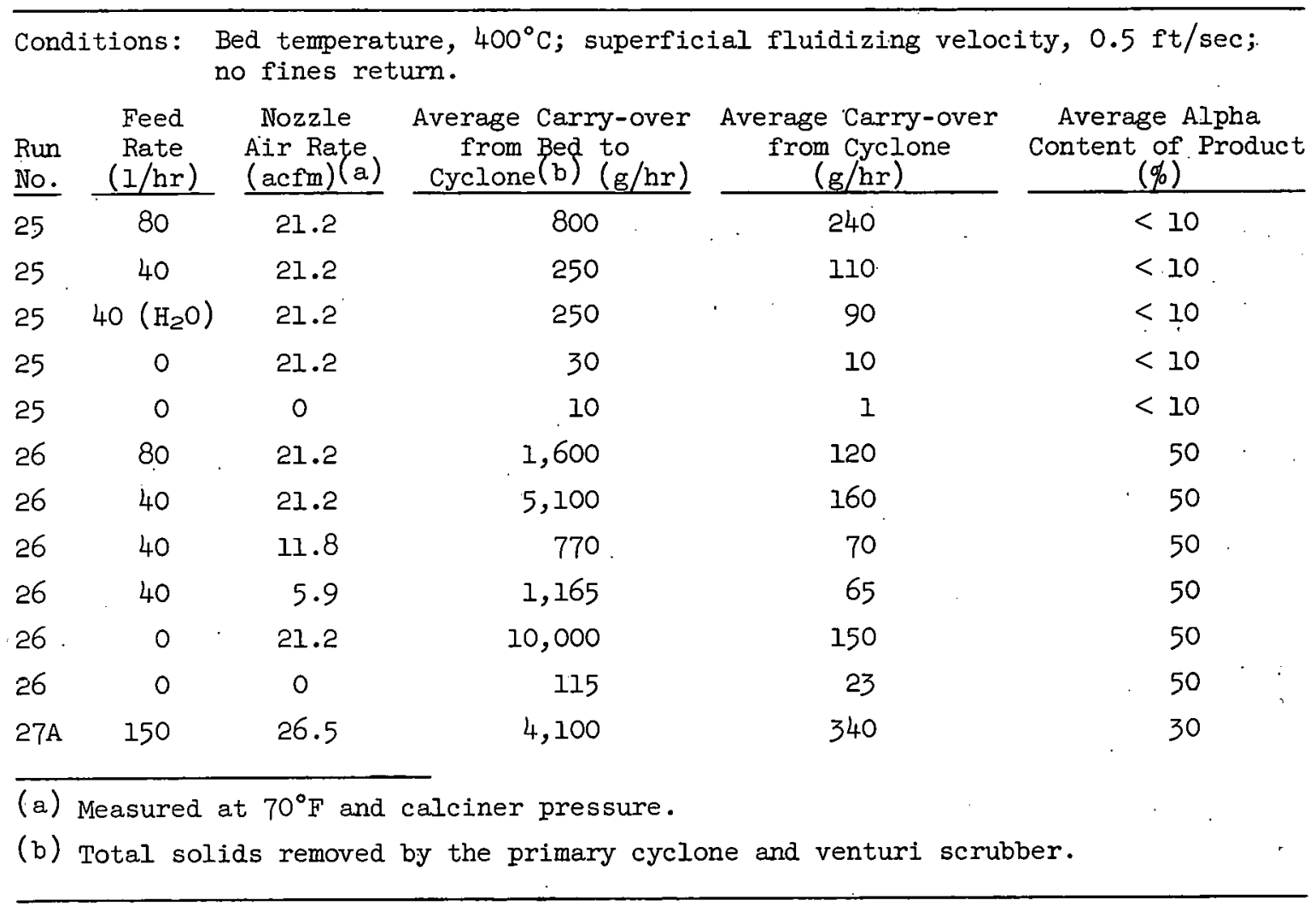

carry-over obtained with an amorphous bed while fluidizing and using nozzle air, but not introducing feed. With high alpha alumina content beds, more of the elutriated solids apparently originate from breakdown of the bed particles; however, a substantial portion of these elutriated solids are also freshly generated. This was borne out by a comparison of the alpha alumina content of the product and cyclone fines in run 26. The fines analyzed about 25 per cent alpha alumina at a time when the product averaged twice that value. Other supporting evidence is found in the fact that, on previous pilot plant and DWCF runs, the composition of solids carried over from the calciner responded rapidly to changes in feed composition while the composition of the bed responded slowly. The identical elutriation rates obtained when substituting water for feed in run 25 eliminates spray drying as a significant mechanism for fines generation.

\subsection{Effect of Nozzle Location}

Short tests were made to determine the effect of locating the nozzle above or below the NaK tubes or above the bed. No appreciable change in operability of solids carry-over was detected by changing nozzle locations from above to below the $\mathrm{NaK}$ tubes. Introduction of feed onto the surface of 
the bed at an angle of $45^{\circ}$ resulted in caking on the calciner walls above the bed. The solids carry-over rate from the calciner increased under this mode of operation; however, the solids carry-over from the cyclone changed very little.

\subsection{Effect of Alumina Structure}

On these runs, boric acid was added to the feed when an amorphous alumina product was desired, and sodium nitrate was added when a high alpha alumina content product was desired; these additives had the desired effect in all cases. Operability while fluidizing a small particle size, high alpha alumina content bed at a superficial velocity of 0.5 foot per second was satisfactory and permitted use of liquid feed rates up to 150 liters per hour. Excessive particle growth with amorphous beds under similar conditions precluded use of as high a liquid feed rate.

\section{LABORATORY STUDIES OF STAINLESS STEEL CALCINATION (D. W, Rhodes, Problem Leader; F. M, Vander Wa11)}

Thermal decomposition studies were conducted on hydrated nitrates of iron, nickel, and chromium, which are the principal constituents of wastes formed: during processing of stainless steel fuels by either the Darex or electrolytic processes. Similar studies on aluminum nitrate decomposition provide a basis for comparison.

Principal findings from these studies are summarized in Table VI. It will be noted that complete decomposition is achieved with stainless steel component nitrates at temperatures approximating those used for aluminum nitrate calcination. Intermediate compound formation was indicated in the case

\section{TADI T VI}

THERMAL DECOMPOSITION OF STAINLESS STEEL AND ALUMINUM NITRATES

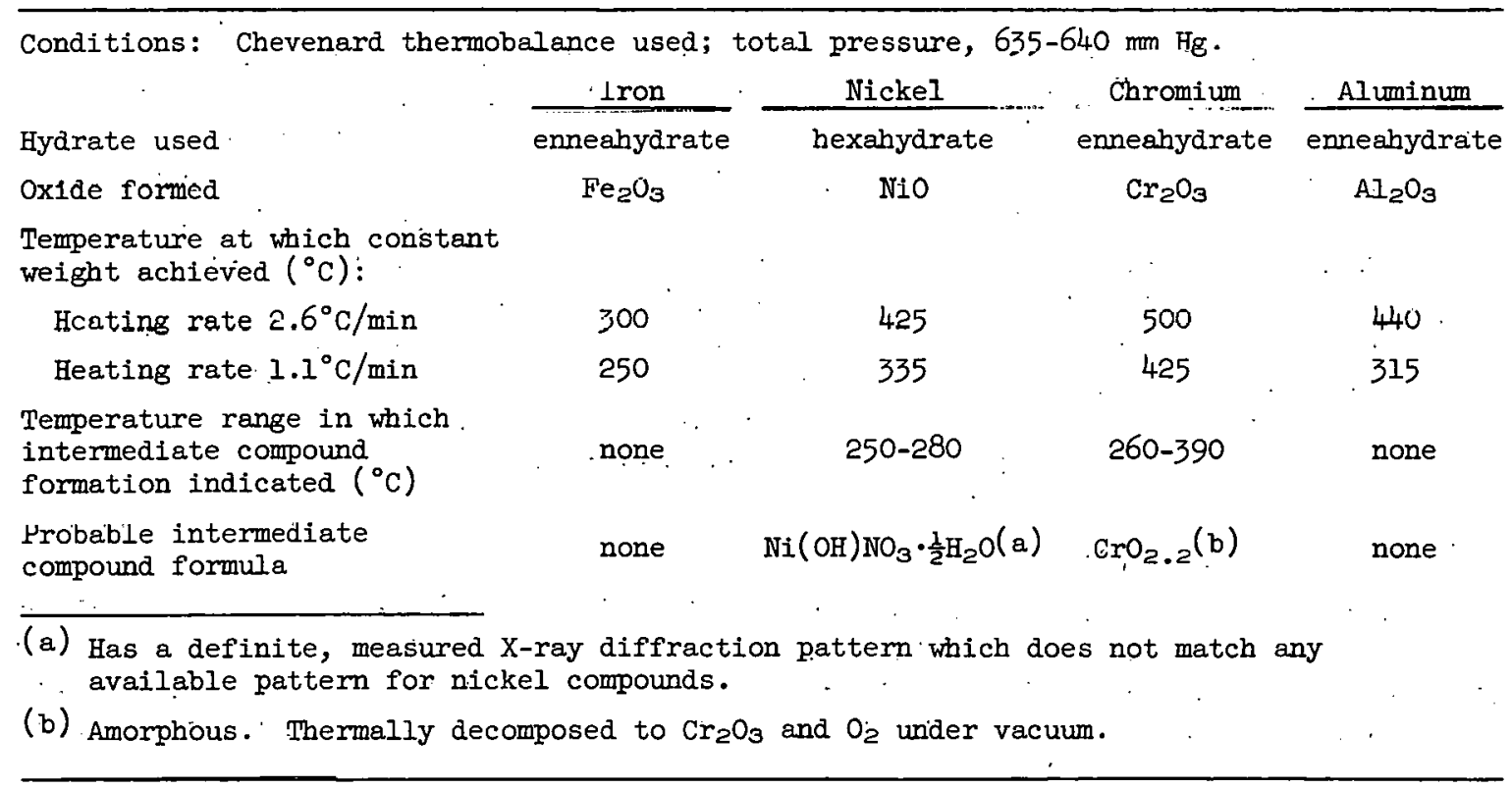


of nickel and. chromium nitrate decomposition but not in the case of iron and aluminum nitrates. One of these compounds, apparently $\mathrm{Ni}(\mathrm{OH}) \mathrm{NO}_{3} \cdot 1 / 2 \mathrm{H}_{2} \mathrm{O}$, has a definite X-ray diffraction pattern which does not match any available pattern for nickel compounds. The other intermediate substance has the empirical formula $\mathrm{CrO}_{2.2}$ and is amorphous.

\section{POT CALCINATION}

(B. R. Wheeler, Problem Leader)

In collaboration with ONRL personnel, the process flow sheet was revised for the hot pilot plant installation to demonstrate the pot calcination process. Equipment layout drawings were prepared for the installation in cells 1 and 2 of the recently completed Hot Pilot Plant. Based on the revised flow sheet, detailed equipment drawings are being prepared; priority is being given to critical items as indicated by a critical path scheduling diagram. 


\section{BASIC PROCESS STUDIES AND EQUIPMENT DEVELOPMENT}

(Section Chief: J. I. Stevens, Development Engineering)

1. EXPERIMENTAL AIR PULSER

(E. E. Erickson, Problem Leader; S. J. Horn)

Operating data on the experimental air pulser [10] have been obtained for single-phase operation with water at frequencies of 30,40 , and 60 cycles per minute. The pulse amplitude was determined by direct, visual observation of the position of the air-water interface within the glass pulser leg.

The measured pulse amplitudes are compared in Figure 8 with the data obtained by simulating the pulser and column on the analog computer. The general equations for the simulation have been described elsewhere [10]. In most instances, the experimental results are within \pm 5 per cent of those obtained by analog simulation.

\section{PULSE COLUMN DYNAMICS}

(E. E. Erickson, Problem Leader;

$$
\text { J. L. Lockard). }
$$

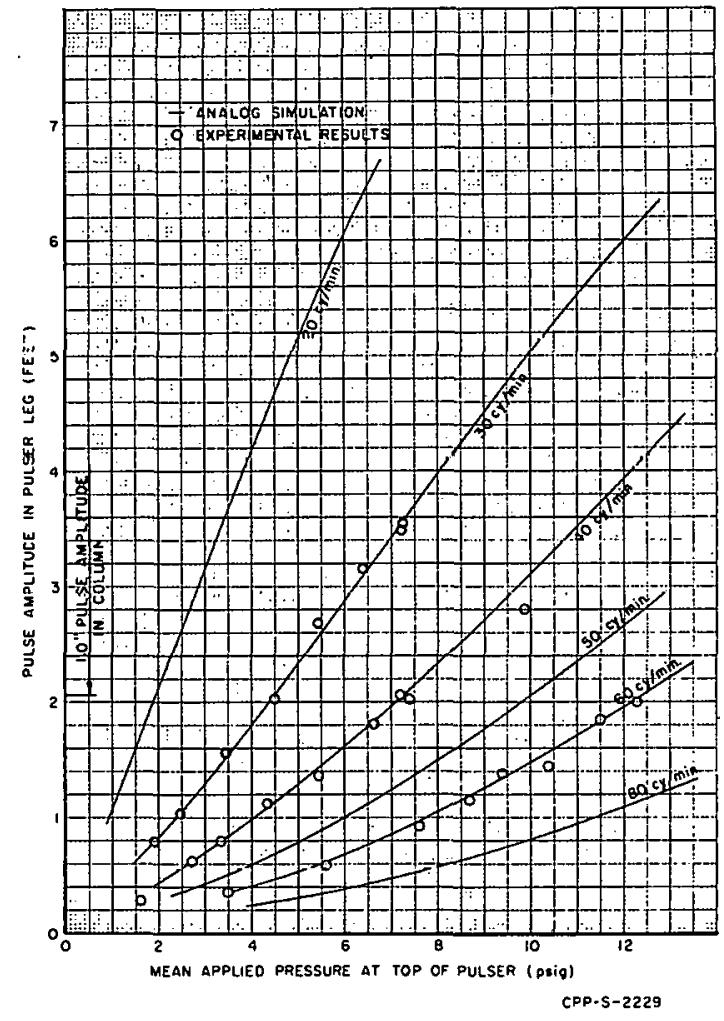

Fig. 8 Pulse amplitudes in experimental air pulser.

As an initial step in a study of pulse column dynamics, a study undertaken in order to specify and evaluate column control requirements, a suitable technique for sampling the individual phases (aqueous and organic) present in an operating column is being developed. Complete separation of the phases of a finely dispersed, equal-volume mixture of Amsco in water was obtained in sampling experiments by using grade $D$ porous stainless steel for the aqueous phase and porous Kel-F for the organic. An aqueous flow rate of $0.2 \mathrm{ml} /\left(\mathrm{cm}^{2}\right)(\mathrm{sec})$ was obtained at about 8 inches of water pressure drop; the same rate of organic was obtained at about 20 inches of water. For successful operation of the samplers, the filters had to take advantage of the density difference of the phases by facing upwards for aqueous and downward for organic. Vertical placement of the filter faces had been satisfactory for phase separation in the hexone-water system.

Flow pulsation and excessive noise in the 900-cycle/minute McCannameter pumps for the laboratory pulse column were traced to air entrainment and the resulting two-phase flow. Air chambers of $3 / 8$-inch tubing, 8 inches long, installed near the suction and discharge ports of the pump heads, have eliminated the difficulties. 


\section{EVAPORATOR CONTROL}

(E. E. Erickson, Problem Leader; L. A. Jobe)

Further study of the cascade-controlled first cycle product evaporator [1, 3] indicates that control is satisfactory where density probes are in either the evaporator cold leg or in the calming legattached to the cold leg. The previously determined time constant of approximately 70 minutes for this system was substantiated by a transient test using a 3- to 5-minute steam pulse. An increase in plant processing rate of approximately 60 per cent is attributed to the new evaporator design and the cascade control system.

\section{CALCULATIONAL TECHNIQUES FOR} DETERMINING EFFECTS OF NUCLEAR POISON

(E. E. Erickson, Problem Leader; W. G. Morrison, D. R. Metcalf)

\subsection{Development of Calculational Methods}

Reactor physics type calculations were continued [11] for the purpose of comparing the calculated values with experimental values which had been obtained at the Rocky Flats Plant on a 36-inch-diameter upright cylindrical tank containing vertical uniformly spaced, boron-stainless steel poison plates and uranyl nitrate solutions [12]. Multiplication measurements in these experiments indicated the extrapolated critical heights for three U-235 solution concentrations, each with a different edge-to-edge plate spacing. Using these results as variables, calculational methods for similar systems of poison plate storage tanks for the CPP have been developed.

A brief discussion of the two methods of approach (cell theory and blackness theory) to the problem, as well as results for the blackness theory method, has been reported [11]. Table VII summarizes the results for cell theory and flux-weighted thermal constants based on the local flux distribution using

TABIE VII

COMPARISON OF CALCULATIONAL METHODS FOR UNIFORM PLATE SPACING

\begin{tabular}{|c|c|c|c|c|}
\hline $\begin{array}{l}\text { Test } \\
\text { No. }\end{array}$ & $\begin{array}{c}\text { 93\% Enriched } \\
\text { Uranium } \\
\text { Concentrate }(\mathrm{g} / \mathrm{I}) \\
\end{array}$ & $\begin{array}{l}\text { Plate } \\
\text { Spacing } \\
\text { (in.) } \\
\end{array}$ & $\begin{array}{c}\text { Eigenvalue } \\
\left(k_{\text {eff }}\right)\end{array}$ & $\underset{\left(k_{e f f}\right)}{\substack{\text { Eigenvalue } \\
(b)}}$ \\
\hline$I$ & 218 & 1 & 0.9998 & 1.0008 \\
\hline 2 & 236 & $1-1 / 2$ & 0.9951 & 0.9992 \\
\hline 3 & 106 & $2-1 / 8$ & 0.929 & 0.9296 \\
\hline
\end{tabular}

(a) Two group, 2 region (annular space is one region), DMM 650 prograw.

(b) Four group, 2 region (annular space is one region), DMM 650 program. 
experimentally determined critical heights, solution concentrations, plate spacings, and plate composition to calculate keff. The consistently low value of $k_{\text {eff }}$ in test 3 , by all the calculation methods tried, indicates an error may have been made in the critical height extrapolation of the experimental results.

The experimental system was considered as two concentric cylinders for the DMM 650 program. The inner cylinder was a homogenized region of fuel in solution and boron-stainless steel poison plates. Region 2 was the solution annulus between the ends of the plates and the vessel wall. MUFT-R was used to determine the fast constants on the basis of a homogenized system. The FLIP-1 IBM 704 program was used to determine the flux-weighted thermal diffusion constants; this permits considering the heterogeneous poison plate solution region as homogenized. The calculated results using cell theory gave better agreement with the experiment.s than results using blackness theory.

\subsection{Modification of Methods for Non-uniform Plate Spacing}

Modification of the calculational terhniques developed for uniform plato spacing of the Rocky Flats experiments has been undertaken to optimize spacing of the poison plates for CPP storage tanks. Plant equipment economics motivated this study. Because the poison concentration in an optimum plate spacing arrangement is not uniform over the entire poison plate region, it was found necessary to use slab geometry and $n$-regions ( $n=$ number of poison plates) rather than the cylindrical geometry and two regions used previously. For one-dimensional diffusion theory, the slab geometry requires development of a method for handling the small regions of poison-free solution at the ends of each slab which result from including the annulus between the overall poison-plate region and the vessel wall. Based on the Rocky Flats experiment with uniform 1-inch edge-to-edge plate spacing and 318-g U/1 solution concentration, several methods for treating the annular region were investigated and are listed below. In this investigation, the differences in the $\mathrm{k}_{\text {eff }}$ were compared for the two methods of treating the annulus.

Case 1: $k_{\text {eff }}=0.9952$ for 2 group -2 region, cylindrical geometry, cell theory. The inner region consists of homogenized plates and solution, the outer region also consists of homogenized plates and solution with the same nuclear constants.

Case 2: keff $=1.0009$ for 2 group -2 region cylindrical geometry, cell theory. The inner region consists of homogenized plates and solutions, the outer region or annulus consists of solution only.

Case 3: $k_{\text {eff }}=1.0182$ for 2 groun -2 n-regions, slab geometry, blackness theory (separate plates and solution regions). The plates and solution extend to the vessel wall, ie, no annulus.

Case 4: $k_{\text {eff }}=1.0370$ for 2 group -2 -regions, slab geometry, blackness theory with an annulus between the ends uf the plales and vessel wall. Thermal constants of the plates were weighted according to the thermal flux (cosine distribution) along the length of the plate to account for the solution at the end of the plate:

Case 5: keff $=0.9982$ for 2 group - n-regions, slab geometry, cell theory. The separate regions of solution plus $1 / 2$ of each of 
adjacent plates extend to the vessel wall, ie, with no annulus. FLIP-1 thermal constants used to obtain results in Table VII, test 1 , were used without weighting.

Case 6: $\mathrm{k}_{\text {eff }}=1.0084$ for 2 group - n-regions, slab geometry, cell theory, with solution annulus at end of plates. The FLIP-1 thermal constants were weighted according to the thermal flux cosine distribution as in case 4 .

The reactivity difference in cases 3 and 4 is unusually high compared with that for cases 1 and 2 (cell theory) which indicates that the use of weighted blackness theory constants is not valid. The reactivity difference for cases 5 and 6 is less than twice that for cases 1 and 2, so the model appears to be adequate for such calculations. Studies are continuing on the adequacy of the model for non-uniform, vertically spaced (optimized spacing) poison plates in cylindrical tanks. 


\section{REPORTS AND PUBLICATIONS ISSUED DURING THE QUARTER}

IDO-14564, An Evaluation of Four Processes for Recovering Uranium from Zirconium Fuels at the Idaho Chemical Processing Plant by P. Burn.

IDO-14568, Tests of a Vapor-Space Feed Nozzle for Calcining Aluminum Nitrate Solutions in a Fluidized Bed by G. E. Lohse

IDO-14570, Stainless Steel Wastes: III. Laboratory Studies of the Rate of Removal of Stainless Steel Ions by Mercury Cathode Electrolysis by D. R: Anderson and D. W. Rhodes

IDO-14572, A Bench Scale Natural-Recirculation Dissolver by E. E. Erickson

IDO-14573, Electrolytic Dissolution of Reactor Fuel Element Materials: Part I. Zirconium in HCl-Methanol by J. R. Aylward, E. M. Whitener, H. T. Hahn

IDO-14578, Salt Phase Chlorination of Reactor Fuels: III. Catalyzed Dissolution of Uranium Dioxide in Lead Chloride-Chlorine System by E. M. Vander Wall, D. L. Bauer, H. T. Hahn

IDO-14579, Salt Phase Chlorination of Reactor Fuels: IV. Niobium Behavior in the Lead Chloride and Chlorine-Lead Chloride Systems by J. L. Teague, H. T. Hahn, E. M. Vander Wall. 


\section{REFERENCES}

1. J. R. Bower, Ed., Chemical Processing Technology Quarterly Progress Report, 4th Qtr 1961, IDO-14583 (1962).

2. J. R. Bower, Ed., Chemical Processing Technology Quarterly Progress Report, 2nd Qtr 1960, IDO-14534 (1960).

3. J. R. Bower, Ed., Chemical Processing Technology Quarterly Progress Report, 3rd Qtr 1961, IDO-14574 (1961).

4. R. E. Blanco, Chemical Technology Division, Chemical Development Section B, Quarterly Progress Report, July - September 1961, ORNL-TM-81 (January 1962).

5. A. L. Allen et al, Electrochemical Preparation of Uranium Tetrafluoride, Part I, Low Temperature Cell, K-680 (November 1950).

6. ANL-4820, (1952) (Secret).

7. O. W. Parret, Modifications for the STR Fuel Recovery Process, IDO-14522 (December 1960).

8. J. R. Aylward, E. M. Whitener, Electrolytic Dissolution of Nuclear Fuels, Part III, Stainless Steel (304) in Nitrate Solutions, IDO-14584 (In process of being issued).

9. J. R. Bower, Ed., Chemical Processing Technology Quarterly Progress Report, 1st Qtr 1961, p 73, IDO-14560 (1961).

10. M. E. Weech et al, Interim Report on the Development of an Air Pulser for Pulse Column Applications, IDO-14559 (September 22, 1961).

11. MTR-ETR Technical Branches Quarterly Report, 4th Qtr 1961, IDO-16760, p 5 (1962).

12. C. L. Schuske, G. H. Bidinger, Nuclear Safety Measurements on Systems Containing Boron and Enriched Uranium, RFP-246 (October 24, 1961). 
PHILlips

PETROLEUM

COMPANY

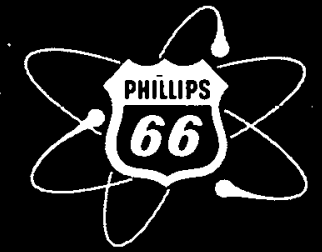

ATOMIC ENERGY DIVISION 